\title{
Construção do Estado e identidade nacional na Grã-Bretanha ${ }^{1}$
}

WolfGAng KNÖBL

Resumo: Analiso como os historiadores "transformaram" a história e a identidade inglesa em britânicas, a despeito da história da Escócia, País de Gales e Irlanda. A supremacia inglesa pode ser explicada pela emergência das estruturas administrativas durante o medievo. $\mathrm{O}$ estudo estabelece ainda relações entre as questões de identidade religiosa e a ascensão do nacionalismo inglês/ britânico. Por fim, aponta que algumas questões teóricas relevantes acerca desse nacionalismo devem ser mais bem exploradas.

Palavras-chave: Estado-nação; Identidade; Grã-Bretanha.

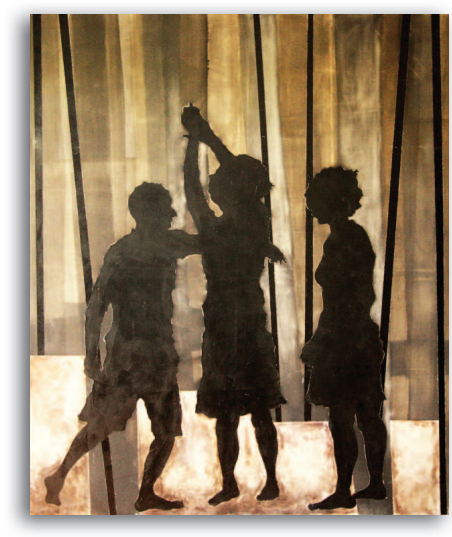

\section{State-building and National Identity in Britain}

\section{WOLFGANG KNÖBL}

Doutor em Sociologia e professor na Universidade de Göttingen; professorvisitante na New School for Social Research (EUA), Universidade de Toronto (Canadá) e no Colégio Max Weber da Erfurt University (Alemanha).

\begin{abstract}
I analyze how historians "changed" the history and English identity in Britain, despite the history of Scotland, Wales and Ireland. The supremacy of English can be explained by the emergence of administrative structures during the Middle Ages. The study establishes further links between the issues of religious identity and the rise of English/British nationalism. Finally, it points out that some relevant theoretical questions about that nationalism should be further explored.
\end{abstract}

Keywords: Nation-State; Identity; Great Britain.

1 Nota do autor: Este artigo foi originalmente escrito como parte do Projeto VW (coordenado por Wolfgang Knöbl, Matthias Koenig e Willfried Spohn), sob o título alemão de "Europäisierung, multiple Modernitäten und kollektive Identitäten - Religion, Nation und Ethnizität in einem erweiterten Europa". 


\section{INTRODUÇÃO}

Estou usando o termo "história britânica" [...] para denotar a história plural de um grupo de culturas situadas ao longo de uma fronteira anglo-céltica e marcadas por uma crescente dominação política e cultural inglesa. A história da Escócia em relação à Inglaterra no século XVII, como a do Reino Unido em relação à Europa no século XX, é a história da progressiva absorção de uma cultura política por um complexo cultural vizinho cujos conflitos ela não consegue dominar; mas a Escócia não é mais inglesa do que a Grã-Bretanha é europeia (J. G. A. Pocock).

Não há exagero em afirmar que, em 1975, estas frases marcaram o início de um novo campo de pesquisa na historiografia de língua inglesa. Elas estavam no centro de um ensaio de J. G. A. Pocock, intitulado História britânica: um apelo por um novo sujeito [British history: a plea for a new subject] (POCOCK, 1975a, p. 605; destaque do autor). O título, com certeza, era uma enorme provocação, assim como a principal tese do ensaio: Pocock, de fato, acusa a duradoura e, por vezes, brilhante tradição da historiografia britânica de ter se furtado a esclarecer o relacionamento cultural, político, econômico, etc., entre a Inglaterra e as outras partes do "arquipélago Atlântico".

com muita facilidade, afirma Pocock, assumiu-se que a Inglaterra era e é Grã-Bretanha, o que também significou que questões relacionadas ao "quando" e "como" da (tentada) incorporação e integração da Escócia, do País de Gales e da Irlanda à GrãBretanha não foram postas de modo algum. Do ponto de vista dos historiadores ingleses, a história da Inglaterra foi simplesmente a da Grã-Bretanha. Evidentemente, sempre houve profícuas tradições de pesquisa dentro da historiografia irlandesa, gaulesa e escocesa, que poderiam ter equilibrado a parcialidade dos historiadores ingleses. Entretanto, trabalhos vindos destas tradições não-inglesas costumavam negligenciar, igualmente, a questão da "britanicidade": a história da Irlanda, do País de Gales e da Escócia era normalmente escrita apartada dos eventos e processos no resto do "arquipélago Atlântico", de modo que permanecia obscuro como a história gaulesa, irlandesa ou escocesa veio a ser e é também história britânica.

Certamente não por acaso Pocock foi o responsável por iniciar a reorientação da historiografia britânica: historiador neozelandês, especializado em transferências culturais entre Itália, Inglaterra e 
América do Norte durante o início do período moderno (POCOCK, 1975b), ele estava talvez mais sensibilizado do que qualquer outro com a fluidez das fronteiras culturais e com o entrelaçamento de diversos processos culturais. Porém, a intervenção acadêmica de Pocock (1982) certamente não surgiu do nada. O panorama político da Grã-Bretanha já tinha sido transformado desde meados dos anos 1960.

Embora nas duas décadas que se seguiram ao fim da Segunda Guerra Mundial a Grã-Bretanha parecesse uma estrutura monolítica, isso começou a mudar com certa rapidez. A ascensão e o sucesso do Partido Nacional Escocês (Scottish National Party - SNP), por exemplo, evidenciaram que a "Grã-Bretanha" não é e não será uma estrutura política aceita por todos, de modo que, desde a década de 1970, "a fragmentação da Grã-Bretanha" (NAIRN [1977] 1981; MARR, 2000) esteve na agenda política, uma agenda que também foi crescentemente influenciada pelos processos da integração europeia: "Qual é a raison d'être da Grã-Bretanha ou do Reino Unido"? Tais questões eram feitas com frequência cada vez maior. E as respostas eram geralmente estas:

Serviu a seu propósito nos grandes dias do Império Britânico, quando todos os grupos nacionais dentro das Ilhas Britânicas exerceram um papel - em graus variados - na sua conquista, administração, conversão ao cristianismo e seu desenvolvimento comercial. Aqueles dias chegaram ao fim. Assim como o Reino Unido teve de se adaptar, com dificuldade, à emergência da "Europa", também suas partes tiveram de encontrar um novo tipo de relacionamento (ROBBINS, 1993, p. 230; CANNADINE, 1995).

Desde aquele tempo, prossegue a busca por uma "História britânica", o que também significa a continuidade da busca pelos vários componentes da identidade britânica; pela relação entre identidade inglesa, gaulesa e escocesa; e pelo relacionamento entre cada uma delas e uma pretensa abrangente identidade "britânica". Isto, como se demonstrará nas páginas seguintes, dificulta ainda mais formular um esboço histórico-sociológico da construção da nação e do Estado britânico (e/ ou inglês), porquanto, na historiografia britânica, a maioria dos elementos teóricos centrais é fortemente contestada, sejam as origens do patriotismo ou nacionalismo britânico ou inglês, 
sejam os grupos portadores deste nacionalismo, seja a morfologia da identidade britânica.

Portanto, gostaria de esclarecer as premissas da minha narrativa tanto quanto possível: começarei com algumas das observações de Pocock sobre os diferentes loci de poder dentro do "arquipélago Atlântico" durante os tempos medievais e depois focalizarei a emergência das estruturas administrativas do lócus de poder inglês, já que a Inglaterra foi o "agente" decisivo na região. A seguir, farei um esboço do desenvolvimento do panorama religioso da Inglaterra/Grã-Bretanha, começando pela formação da Igreja da Inglaterra, nos anos 1530, e culminando com o "Ato de União" entre a Inglaterra e a Escócia, em 1707. Este será, então, o plano de fundo para a discussão de interpretações discordantes acerca da ascensão do nacionalismo inglês/britânico, um nacionalismo que, como se verá, está profundamente entrelaçado com questões de identidade religiosa. Obviamente, esta seção tenta, ao mesmo tempo, fornecer um curto relato histórico-sociológico do desenvolvimento do nacionalismo britânico desde o início do século XVIII até o início do século XX. Uma breve conclusão irá apontar as necessidades de pesquisa e ressaltar algumas questões teóricas não resolvidas.

\section{CONSTRUÇÃO DO ESTADO E DO IMPÉRIO NAS ILHAS BRITÂNICAS: DA IDADE MÉDIA AO SÉCULO XVIII}

Como resumido por Pocock (1975b, p. 607), o lócus mais dinâmico "de governo, aplicação da lei e serviço ao rei" na era pós-romana foi o reino de Wessex-Mércia e East Anglia (depois chamado Inglaterra), no sul das Ilhas. A despeito de este lócus de poder ter sido consolidado pela conquista normanda do século XI, não foi capaz de penetrar e controlar imediatamente as regiões adjacentes, especialmente aquelas mais ao norte. A região conhecida como Escócia, separada do sul pelas terras altas da Northumbria, conseguiu manter certo tipo de independência e peculiaridade, embora processos de anglicização pudessem ser detectados em um estágio bem inicial. De qualquer modo, ambos os reinos, Inglaterra e Escócia, foram profundamente influenciados pelas "tradições da igreja, lei e administração" da Europa continental 
(POCOCK, 1975a, p. 608) e eram fortes o bastante para expandir suas esferas de influência sobre as regiões ainda não subjugadas. A partir da ideia de Owen Lattimore acerca do relacionamento entre impérios e fronteiras, Pocock argumenta que, em volta das "zonas fronteiriças militarizadas" da Inglaterra e Escócia, surgiram "primeiro, uma contra a outra, nas disputadas terras das regiões altas da Northumbria e, segundo, cada uma contra seus vizinhos da área celta não incorporada: Gales, no sul, e as Ilhas e Terras Altas Gaélicas, no noroeste" (POCOCK, 1975a, p. 608).

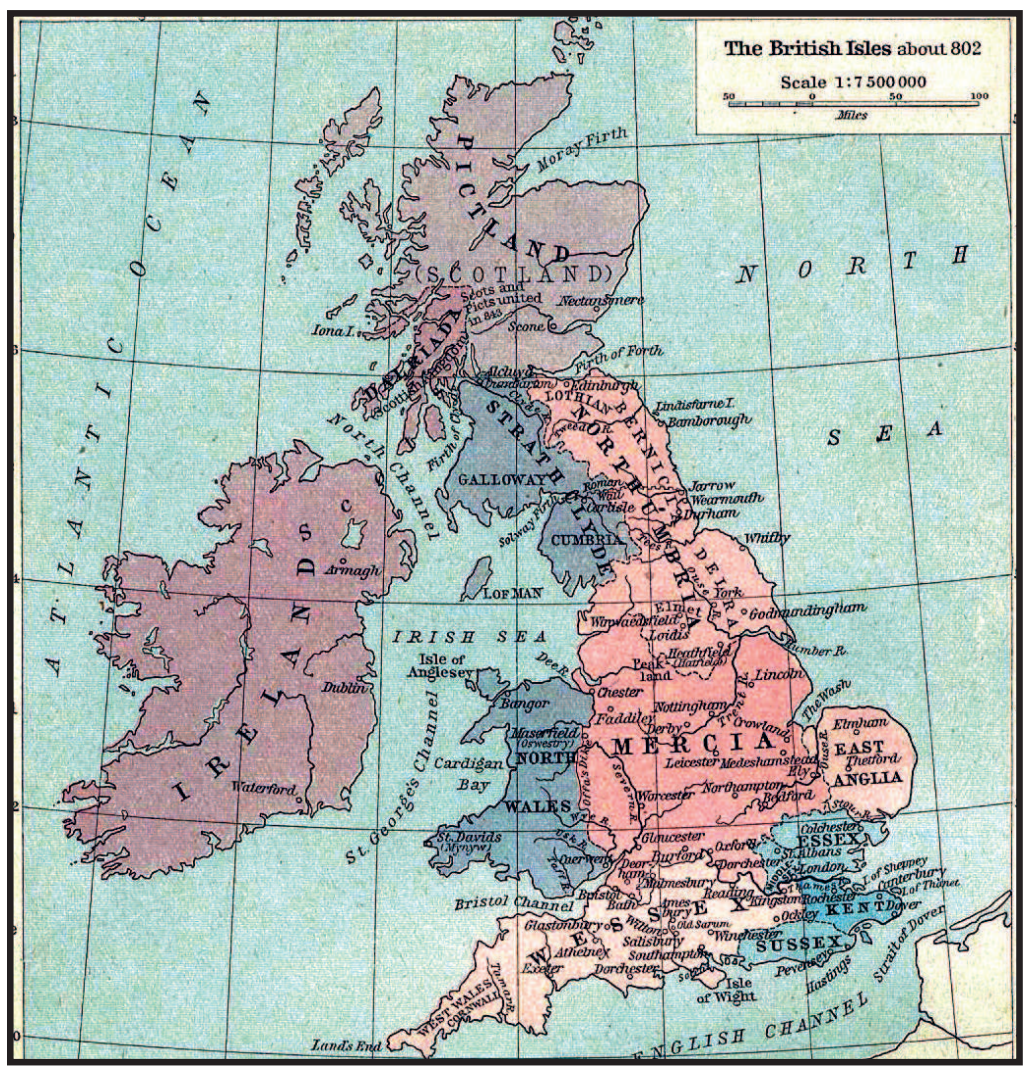

Figura 1 - Mapa das Ilhas Britânicas por volta de 802

Fonte: Atlas Histórico de William Shepherd, 1923, p. 60. 
Assim, desde o princípio da conquista normanda, as ilhas foram fortemente disputadas. As relações entre Inglaterra, Escócia, Gales e Irlanda (aquelas "ilhas a noroeste") sempre foram bem complexas, pois certamente havia diferentes identidades regionais que poderiam ter sido usadas como recursos na disputa de poder em curso. Para piorar a situação, esta disputa de poder sempre teve, também, um aspecto continental, já que os governantes da Inglaterra, este reino, no sul, ainda tentaram dominar a França, pelo menos até o século XV.

Deixando toda esta "história multicontextual" ou "plural" (POCOCK, 1982, p. 320) para outro momento, é bastante óbvio que a Inglaterra, como o lócus de poder mais dinâmico, tinha algumas peculiaridades que são importantes comentar, porque explicam, em parte, o curso posterior da história de todo o "arquipélago Atlântico". Pelo menos três pontos politicamente relevantes deveriam ser, de modo sistemático, destacados neste contexto:

1) Já nos séculos XII e XIII, a Inglaterra era mais ou menos um Estado unitário² com uma administração real e um sistema legal unitário (STRAYER, 1970, p. 31; ANDERSON, 1979, p. 142; GERSTENBERGER, 1990, p. 46). Bem diferente do ocorrido no continente europeu, na Inglaterra, não surgiu nenhum território aristocrático autônomo possível de ter ameaçado o poder da Coroa. Em consequência, um monopólio real de violência foi estabelecido logo cedo (KRIEGER, 1990, p. 132). Desse modo, o esfacelamento do poder político - tão típico do feudalismo europeu - foi evitado, com implicações peculiares para a posição da aristocracia inglesa: enquanto, no continente europeu, a maioria dos senhores feudais podia defender suas posições de poder contra a Coroa, na Inglaterra, a aristocracia apenas podia usar seu poder em cooperação com a Coroa. Dada sua forte dependência do sucesso militar do rei, de posições administrativas e de benesses, a nobreza inglesa jamais teve interesse de fato em uma autoridade real fraca e sem poder (GERSTENBERGER, 1990, p. 73).

2 Estou ignorando a questão acerca de o conceito de Estado se aplicar ou não no contexto Inglaterra/Grã-Bretanha, visto que seus sistemas políticos não eram liderados por administradores, mas por magistrados e representantes (POCOCK, 1982, p. 319). Ver também Dyson (1980). 
Exatamente por conta desta identificação de interesses entre nobreza e Coroa, os governantes ingleses não tinham necessidade de construir aparatos militares centrais para prevenir rebeliões feudais; pelo contrário, eles podiam deixar tarefas administrativas a cargo da aristocracia local (STRAYER, 1970, p. 47; CORRIGAN; SAYER, 1985, p. 16). Sobretudo nos condados, muito rapidamente se estabeleceu um sistema de "autoadministração aristocrática não-remunerada" (ANDERSON, 1979, p. 145) que vigorou quase inalterado até o século XVIII e XIX, e que regulou todas as causas associadas a problemas locais de governo, justiça e assuntos de polícia.

Contudo, a nobreza não tinha sua base de poder apenas na esfera local. Por meio do Parlamento (desde o século XI), ela também exercia influência crescente na "grande política" de todo o reino, influência, no entanto, que devia compartilhar com outros grupos privilegiados. ${ }^{3}$ Como era típico do Parlamento inglês, não havia nenhuma cisão evidente entre os diversos estratos, bem diferente do continente europeu! Embora houvesse, com a Casa dos Lordes, uma câmara constituída pelos membros de uma elite aristocrática que era quase como uma casta (o "Pariato"), também é verdade que na câmara baixa, a Casa dos Comuns, não somente o resto da nobreza, bispos e cidades estavam representados, mas também muitos dos filhos do Pariato (CORRIGAN; SAYER, 1985, p. 28). Esta mistura de múltiplos grupos foi a base para a emergência de uma estrutura política representativa, de certo modo unitária, sem fronteiras claras entre os diferentes estratos (ANDERSON, 1979, p. 144) e sem conflitos profundos entre os vários "partidos" e grupos parlamentares. Em virtude de esta instituição mais ou menos unitária ter influenciado estruturas e processos também fora do Parlamento, o resultado foi uma sociedade caracterizada bem menos por conflitos entre nobreza e burguesia do que, por exemplo, a Prússia (SCHRÖDER,1986, p. 69; KLUXEN, 1983, p. 21; LACHMANN, 1989).

3 A Escócia possuía seu Parlamento próprio desde o século XIII. 
2) A relação mais ou menos consensual entre a Coroa e os estratos, e a participação da "nação" na administração dos assuntos locais e do Estado desde o século XIV (BENDIX, 1980, p. 284) não foi realmente desafiada nos séculos seguintes. Assim, tornou-se possível desenvolver uma orientação constitucionalista. Certamente, houve pelo menos algumas tentativas dos governantes ingleses de seguir o caminho absolutista dos monarcas do continente europeu. Contudo, isto jamais se efetivou - em parte pelo fato de que, como resultado da devastadora Guerra dos Cem Anos, na França (1337-1453), e a conhecida "Guerra das Rosas", entre as casas de York e Lancaster (14551487), a Inglaterra começou a diminuir seu envolvimento em assuntos continentais.

No longo prazo, isto teve um efeito antiabsolutista, porquanto esta retirada se deu exatamente num momento em que, no continente, a "revolução militar" havia apenas começado (BREWER, 1989, p. 8). Assim, enquanto quase todos os governantes europeus, pela lógica desta revolução militar, tiveram de estabelecer grandes exércitos e centralizar estruturas políticas com vistas a sobreviver aos conflitos do continente, tal artifício não foi necessário nas Ilhas Britânicas, onde não houve sérias ameaças militares externas ou internas: os exércitos ingleses dos séculos XIV e XV, que, com frequência, atemorizaram seus inimigos continentais com sua eficiência militar, perderam rapidamente a imagem intimidadora (BREWER, 1989, p. 8; ANDERSON, 1979, p. 153), de modo que - pelo menos até o final do século XVII - o papel da Inglaterra no cenário da política europeia foi consideravelmente diminuído. Mesmo os governantes Tudors que, após a Reforma Protestante, tentaram centralizar ainda mais o Estado inglês e estabelecer estruturas absolutistas, não foram capazes de reverter esta tendência.

As aventuras militares de Henrique VIII nos anos 40 do século XVI, quando tentou continuar a antiga tradição de intervenção militar na França, foram altamente mal-sucedidas. Não é de admirar ter se passado pelo menos cinquenta anos até que a Inglaterra fosse capaz de influenciar novamente os assuntos continentais (ANDERSON, 1979, p. 155). Mas como o 
estabelecimento de um forte exército inglês permanente não podia mesmo estar seriamente nos planos dos governantes ingleses, a pretendida influência na Europa (e no mundo) deveria ser conseguida por outros meios que não um exército permanente.

Assim, entre os séculos XV e XVII, o exército inglês continuou um tanto pequeno, bem ao contrário do verificado na França e na Prússia, por exemplo. Embora tenha havido períodos em que exércitos maiores estiveram, ao menos temporariamente, presentes nas ilhas (durante a Guerra Civil, no século XVII, sob Oliver Cromwell e James II), estes exércitos jamais ficaram a postos por muito tempo (BREWER, 1989, p. 8), e com certeza não foram a base para estabelecer um aparato político-militar grande e possivelmente repressor.

O novo modelo de exército de Cromwell, às vezes com mais de 70 mil soldados (REINHARD, 1986, p. 201), e o exército de James foram rapidamente vistos como instrumentos de déspotas e tiranos, e causaram enormes sentimentos antimilitaristas (pelos menos aqueles direcionados a exércitos permanentes) nas elites políticas inglesas, que por décadas, e até séculos, fizeram com que fosse praticamente impensável seguir em tal direção (HILL, 1990, p. 19). Desse modo, a Coroa inglesa, ao contrário dos monarcas europeus, nunca foi capaz de conseguir recursos autônomos de poder (militar) e se libertar do Parlamento, o qual sempre controlou rigidamente o orçamento militar (REINHARD, 1986, p. 178).

3) Como deveria estar claro: a posição de poder um tanto instável da Coroa inglesa foi um pressuposto para a emancipação do Parlamento da dominação monárquica. A soberania do Parlamento tornou-se uma característica bem inglesa de alta política nas Ilhas (HAAN; NIEDHART, 1993, p. 172). Levado adiante pelos levantes revolucionários do século XVII, o já minguante poder da Coroa tornou-se ainda mais limitado, especialmente depois da "Revolução Gloriosa" (1688), por uma série de leis:

a) Com a "Carta de Direitos" (1689), o recolhimento de impostos e a criação de um exército permanente em tempos de paz foram considerados ilegais se não tivessem o consentimento do 
Parlamento. Isto foi importante à medida que o resultado foi um debate parlamentar contínuo e recorrente sobre assuntos militares (KLUXEN, 1983, p. 79). Um controle monárquico do exército, tão típico da Prússia até o começo do século XX, estava fora de questão na Inglaterra desde os momentos iniciais da sua história. Desde então, o exército inglês/britânico tem sido um exército do Parlamento.

b) O "Ato Trienal" de 1694 impossibilitou que a Coroa dissolvesse arbitrariamente o Parlamento. Também conforme determinado, a cada três anos deveriam ser realizadas eleições. Desse modo, o ato legislativo estabeleceu as bases para uma completa politização da vida pública e, finalmente, deu ao Parlamento o controle, até mesmo, sobre matérias de política externa, e subordinou a escolha dos ministros ao consenso do Parlamento. Em consequência, o rei/rainha apenas poderia atingir seus objetivos políticos se encontrasse ministros e secretários de Estado com os quais a maioria do Parlamento concordasse. A prerrogativa real acabou; o soberano tinha se tornado "Rei no Parlamento" (SPECK, 1977, p. 14).

c) O "Ato de Estabelecimento" (1701) não apenas determinou independência judicial (da interferência da Coroa), mas também decidiu, de maneira quase revolucionária, sobre a questão da sucessão ao trono. Isto também demonstrou, mais uma vez, a recém-conquistada soberania do Parlamento, e barrou novas tentativas de instalar estruturas absolutistas, tão comuns no continente (VON GREYERZ, 1994, p. 246).

A forte posição do Parlamento e da Inglaterra de desenvolver uma orientação não-absolutista não significa, entretanto, ser aquele um Estado fraco. Certamente, a construção de Estado na Inglaterra foi "excepcional". Porém, quanto à capacidade de mobilizar grupos sociais, o Estado inglês foi altamente bem-sucedido e eficiente. Seus métodos

[...] evidentemente menos visíveis do que os de seus correspondentes europeus, operando através de canais descentralizados, embora intimamente conectados com o governo central, e [o Estado inglês] demonstrou alguma sensibilidade ao perigo de ultrapassar demais os limites do consentimento (THANE, 1990, p. 3). 
E, com efeito, este aparato do Estado inglês, embora bem menor do que o da França absolutista, tornou-se tão eficiente e forte ao fim do século XVII (SPECK, 1977, p. 14) que em um período de tempo consideravelmente curto a Inglaterra/Grã-Bretanha transformou-se na potência mundial dominante.

Uma das razões para a ascensão da Inglaterra tinha a ver com o seu recuo político e militar em relação aos conflitos europeus entre os séculos XV e XVII, o que evitara os altos débitos (para o financiamento da guerra) acumulados pelos maiores Estados continentais (BREWER, 1989, p. 15). Ademais, graças ao fato do Parlamento manter um olhar atento sobre o orçamento da Coroa, a situação financeira naquele país continuou relativamente segura. Assim, quando a Inglaterra, por uma série de razões, algumas delas, como se verá, relacionadas à religião, começava a se interessar novamente por questões europeias em fins do século XVII, seus recursos estavam em tão bom estado que a expansão sem exaustão financeira tornou-se possível (KENNEDY, 1990; KLUXEN, 1983, p. 83).

As guerras contra a Holanda, na segunda metade do século XVII, reduziram o papel do principal rival da Inglaterra na briga pelo controle das rotas marítimas mais importantes. Isto deu às colônias inglesas no continente norte-americano a chance de prosperar, sobretudo porque a França, o outro rival da Inglaterra, também não foi capaz de alcançar seu nível de poder marítimo. As guerras daquela contra a França, entre 1689 e 1973 (o último ano marcando o fim da chamada Guerra dos Sete Anos, travada não apenas nas Américas, mas também no continente europeu), e aquelas do período da Revolução Francesa até 1815, acabaram por assegurar a posição da Inglaterra/Grã-Bretanha no mundo. Embora seu poder incontestável na América do Norte não tenha permanecido por muito tempo, pois a Revolução Americana reduziu consideravelmente o controle inglês/britânico sobre os territórios mais dinâmicos da região, suas recém-adquiridas concessões na Índia (e outras partes do mundo) mais do que compensaram por estas perdas: o antigo Império, com seu centro de gravidade na América do Norte, teve imediata continuidade com um novo, cujo foco principal estava na Ásia (WENDE, 2008, p. 103). Mesmo 
que as conquistas imperiais de novos territórios fossem frequentemente conduzidas por companhias privadas, mais notadamente a Companhia das Índias Ocidentais, não se pode esquecer que tudo isto foi possibilitado e estabilizou-se, sobretudo, por meios militares. "No meio do século XVIII, a Grã-Bretanha tornou-se o maior exemplo no mundo ocidental de um Estado organizado para a efetiva condução da guerra" (LANGFORD, 1989, p. 692).

A emergência deste "Estado militar-fiscal" altamente bem-sucedido (BREWER, 1989; HARLING; MANDLER, 1993), no entanto, também tinha muito a ver com estruturas religiosas e sentimentos nacionais, negligenciados até este momento da minha narrativa. Para este assunto, é necessário que se queira compreender o estranho tipo de identidade britânica ou inglesa referido na introdução. Obviamente, tem-se de, pelo menos, retornar à Reforma Protestante na Inglaterra, isto é, ao reinado de Henrique VIII.

\section{CONSTELAÇÕES RELIGIOSAS NO COMEÇO DA ERA MODERNA: A COROA, A IGREJA DA INGLATERRA E A SOBREVIVÊNCIA DO DISSENSO}

Certamente, concentrar-se na Reforma Protestante de modo a analisar as formas emergentes de patriotismo e nacionalismo não é uma ideia original. Não obstante, apenas com o paradigma da confessionalização ${ }^{4}$ dentro da historiografia nas religiões (europeias) é que este foco em particular foi associado a uma clara perspectiva teórica. Como defendido por Heinz Schilling (1991), não por acaso os séculos XVI e XVII experimentaram as primeiras formas de identidade nacional: a Reforma Protestante e a consequente confessionalização dentro dos territórios católico e protestante aceleraram os processos de modernização e, mais importante para o nosso contexto, de diferenciação nacional. Antes daquele período, em tempos de inegável superioridade católica, a formação de identidades nacionais era particularmente improvável (SCHILLING, 1991, p. 200), tendo em vista que apenas mediante processos de confessionalização é que um contato contínuo e

4 Nota do tradutor: A confessionalização foi um processo que rompeu com a unidade religiosa cristã vigente no período, por via da emergência de diferentes doutrinas, como o calvinismo e o luteranismo. 
intensivo entre instituições políticas e religiosas, de um lado, e a maioria da população, de outro, tornou-se realidade. A criação de laços afetivos para com a "nação" era fundamentalmente dependente dos mecanismos disciplinários que várias instituições estatais e da igreja começaram a desenvolver neste período. ${ }^{5}$

Este argumento, é claro, também se aplica à Inglaterra. Porém, antes de entrar em detalhes, deve-se lembrar de que a Inglaterra Protestante era uma espécie de caso particular, já que, no mapa religioso da Europa, ela estava e está localizada no noroeste de um cinturão de cultura multiconfessional (MADELEY, 2003). Assim, a Inglaterra (e a Grã-Bretanha) foi e é caracterizada pela heterogeneidade de grupos religiosos e igrejas. Um monopólio religioso nunca pôde ser estabelecido. Como veremos,

A despeito de repetidos esforços, durante longo tempo, nas Ilhas Britânicas, o anglicanismo nunca conseguiu se estabelecer como uma tradição dominante na Escócia, Irlanda e no País de Gales; eles resistiram e, ao invés disto, desenvolveram um tipo de alternativa, no caso da Escócia, o estabelecimento presbiteriano e, nos outros dois, a completa extinção anglicana em 1869 e 1914 (efetiva em 1920), respectivamente. Mesmo dentro da Inglaterra, onde o anglicanismo tinha sido restabelecido em 1660, depois de um breve flerte com a tolerância religiosa, durante o período da Guerra Civil, as divergências religiosas apenas podiam ser marginalizadas, nunca erradicadas (MADELEY, 2003, p. 32).

\section{Como isto aconteceu?}

As origens do protestantismo na Inglaterra são bastante conhecidas: ${ }^{6}$ depois que Henrique VIII rompeu com Roma e fundou a Igreja da Inglaterra (a Igreja Anglicana), com a finalidade de legitimar seu divórcio de Catarina de Aragão e seu casamento com Ana Bolena, o Parlamento fez o mesmo e, em 1534, passou o "Ato de Supremacia", que transformou Henrique VIII em líder da nova igreja. Embora o anglicanismo tenha, na prática, preservado muitos dos rituais e doutrinas católicos, a criação de uma nova

5 Isto, é claro, não significa que havia uma consciência nacional detectável durante a Idade Média. O que tem de ser destacado, entretanto, é o fato de que a nação medieval era uma "realidade" apenas para um certo estrato da sociedade, não para a maioria da população (EHLERS, 1991, p. 79). Portanto, parece plausível argumentar com Schilling e outros que "confessionalização" significava algum tipo de salto quântico para o desenvolvimento do nacionalismo popular.

6 Sobre este tema ver o curto panorama em Melnyck (2008, p. 3). 
igreja estatal, quase que por necessidade, significava que os membros das antigas instituições católicas romanas tinham de se reorientar e jurar aliança a Henrique VIII e "sua Igreja". Contudo, a fundação da Igreja da Inglaterra, que deveria ser a única instituição religiosa legítima, não resolveu as questões religiosas. Ao contrário, nos dois séculos seguintes, a Inglaterra viveu um período de grande crise política e religiosa - não muito diferente do verificado no continente europeu.

Estes períodos de crise foram frequentemente causados pela questão da sucessão (protestante) ao trono inglês. Por exemplo, depois dos reinados de Henrique VIII e do seu filho, Eduardo VI, houve um curto, mas muito importante, intermezzo católico, quando a filha de Henrique VIII, Maria ("Maria, a Sanguinária", 15531558), reaproximou a Inglaterra de Roma. Como não hesitou em perseguir aqueles não católicos de maneira implacável (o fato deve ser mencionado já que os chamados "mártires marianos" - 275 pessoas que morreram devido à sua fé protestante - tornaram-se um mito histórico, mais tarde estreitamente relacionado ao protestantismo e ao nacionalismo inglês/britânico), ${ }^{7}$ mas não ficou no poder tempo o bastante para conseguir recatolicizar a Inglaterra, o problema da identidade nacional permaneceu na agenda política do país entremeada com questões de aliança religiosa desde, pelo menos, a metade do século XVI.

Isto ficou claro quando Elizabeth tornou-se rainha, em 1558. Tal como Elizabeth I (1558-1603), ela renovou o antigo "Ato de Supremacia", reforçando a legislação religiosa do seu pai, Henrique VIII, que tinha determinado o status privilegiado da Igreja Anglicana. Ela também alcançou um tipo de acerto entre as diferentes doutrinas protestantes, o qual mais tarde ficou conhecido como "Acordo Elisabetano": o anglicanismo foi deliberadamente codificado de uma forma ampla e geralmente ambígua. Desse modo, os "Trinta e Nove Artigos da Religião" (1563), que definiam os elementos centrais da doutrina anglicana, permitiram que tanto crentes simpáticos ao catolicismo romano quanto aqueles simpáticos a Lutero se encaixassem no sistema da Igreja Anglicana.

7 Para mais sobre este assunto, cf. Schilling (1991, p. 226) e Grabes (1991). 
Com o apoio do Parlamento, estes artigos e o Livro de Oração Comum da Igreja Anglicana, de 1559, se transformaram em uma espécie de lei fundamental da Inglaterra, uma lei que tentava definir "inglesidade". Esta definição protestante de "inglesidade" tornou-se ainda mais distinta quando o conflito entre o Papa, em Roma, e Elizabeth (e a Coroa inglesa em geral) se intensificou, nos anos 1570, e - depois da excomunhão de Elizabeth - pelo menos os católicos romanos não eram mais leais à Coroa britânica, como pôde ser percebido pela "Conspiração da Pólvora", de 1605: quando, sob a liderança de Guy Fawkes, conspiradores católicos tentaram explodir as Casas do Parlamento e matar o rei James I, sucessor de Elizabeth I e primeiro rei da casa de Stuart no trono inglês, ${ }^{8}$ a legislação religiosa tornou-se o instrumento mais importante para a exclusão dos católicos da vida pública, já que o catolicismo parecia ser, de fato, uma ameaça ao trono inglês e suas instituições.

[Já] em 1585, qualquer padre católico em atividade na Inglaterra e em Gales era, por definição, culpado de traição. Nenhuma afirmação de que o Estado era contra o catolicismo poderia se fazer mais clara. Ele era "romano", não um credo para o povo da Inglaterra e de Gales (ROBBINS, 1998, p. 108).

Este ambiente anticatólico, no entanto, não foi reforçado apenas pelos acontecimentos políticos. Não se pode esquecer que a Inglaterra também sofreu ameaças externas, porquanto não somente a França (católica) tentou continuadamente interferir na Escócia e na Irlanda; na Era Elisabetana também ocorreu a tentativa da Espanha (católica) de invadir as Ilhas, o que fracassou miseravelmente em 1588. ${ }^{9}$ Desse modo, as intervenções (católicas)

8 O rei James I era filho de Mary Stuart ("Mary, Rainha dos Escoceses"), sentenciado à morte por ordens de Elizabeth I.

9 John Wolffe resume os motivos para a percepção do catolicismo como uma ameaça à identidade inglesa na seguinte sentença: "O entendimento de que o catolicismo romano representava uma séria ameaça ao Estado era compreensível nos séculos XVI e XVII. A bula papal de Pio V, em 1570, liberou os seguidores de Elizabeth de sua aliança, e foi seguida pela Armada espanhola, pela Conspiração da Pólvora e pelo temor da influência católica durante o reinado de Carlos I. No final do século XVII, a Conspiração Papal imaginária de 1678 levou a um frenesi de sentimento anti-romano e, sob James II, foi feita uma séria tentativa de restabelecer o país ao catolicismo romano. Do mesmo modo, depois de 1688, a sucessão do trono foi limitada aos protestantes: George I e seus herdeiros deviam a Coroa à exclusão de inúmeros católicos romanos, que lhes precediam em termos restritos de direito hereditário. As rebeliões Jacobinas de 1715 e 1745 tinham a finalidade de restaurar os católicos romanos Stuarts e, consequentemente, mantiveram a hostilidade viva. Embora os católicos romanos ingleses não lhes dessem mais do que um apoio simbólico, sua lealdade ainda era questionada" (WOLFFE, 1994, p. 32). 
externas fortaleceram ainda mais o elemento protestante dentro de um sentimento que pelo menos alguns historiadores chamariam de "nacionalismo inglês".

Neste ponto, cabe mencionar que, de acordo com uma das mais proeminentes interpretações do nacionalismo inglês, foi especialmente entre 1540 e 1640 que este nacionalismo veio, forçosamente, a existir: em Nacionalismo - cinco caminhos para a Modernidade (1992), Liah Greenfeld argumenta que, como "inventora" do nacionalismo moderno, a Inglaterra tinha experimentado não uma mera revolução cultural, o que o protestantismo, de fato, era quando Henrique VIII decidiu romper com Roma. Ainda conforme ela defende, o reinado de Henrique VIII viu o surgimento também de uma nova classe: surgiu uma nova aristocracia fundamentalmente diferente da sua antecessora que tentou se legitimar usando e enfatizando a ideia de "nação" (GREENFELD, 1992, p. 47).

Neste discurso, novas traduções da Bíblia para o inglês foram usadas para aclarar os contornos desta identidade nacional emergente: a menção do inglês como um "povo escolhido", por exemplo, deixou bastante evidente que sempre houve um elemento protestante particularmente forte no nacionalismo inglês. Repetindo, este elemento protestante era supostamente impulsionado pelo mito dos mártires marianos, mortos durante o "Governo de Terror" de "Maria, a Sanguinária", um mito transformado em uma das características decisivas do nacionalismo inglês desde então, mesmo que Greenfeld admita que o elemento religioso começasse a perder sua importância nos séculos seguintes (GREENFELD, 1992, p. 66). O discurso de nação teve enormes consequências políticas, em muitos aspectos. Seu principal impacto, no entanto, foi o aumento, quase automático, do poder do Parlamento como a personificação da nação, de modo que a identidade nacional ficou cada vez mais relacionada a uma instituição política mais ou menos representativa. ${ }^{10}$

10 Deve-se destacar a admissão de Greenfeld de que o nacionalismo inicial do século XVI ainda era muito centrado na monarquia; foi apenas a partir do período Stuart (desde o começo do século XVII) que a ideia de nação não foi automaticamente associada com a Coroa (GREENFELD, 1992, p. 71). Para uma crítica aos argumentos de Greenfeld, ver Kumar (2003, p. 104). 
Independente das discordâncias nas interpretações parece óbvio que o trono inglês e o "Estabelecimento Elisabetano" não foram desafiados pelo catolicismo. Pelo menos tão significativos quanto este foram os movimentos que radicalizaram a herança do protestantismo inicial. Como logo ficou claro na Inglaterra, o estabelecimento de uma igreja-estatal anglicana não logrou substituir a Igreja Católica e criar um novo monopólio religioso!

Desde 1530, e quase paralelamente à fundação da Igreja da Inglaterra, emergiram novos movimentos religiosos que deliberadamente se distanciaram muito mais evidentemente de todos os elementos mágicos (e, portanto, católicos) da fé cristã. Assim, o anglicanismo não poderia ter sido a última palavra para estes movimentos. Desse modo, o calvinismo continental tornou-se cada vez mais influente entre diferentes estratos e grupos ingleses. Estes grupos puritanos observaram atentamente todo movimento político que parecesse indicar uma possível recatolicização da Inglaterra. Tais movimentos podiam ser detectados, sobretudo durante o reinado dos reis Stuart! Carlos I (1625-1649), filho de James I, que morreu em 1625, não apenas falhou em melhorar as já difíceis relações (financeiras) entre o Parlamento e a Coroa, como também "flertou" com o catolicismo, os puritanos que, neste ínterim, tinham conquistado muitas posições importantes no Parlamento radicalizaram ainda mais:

Estes membros puritanos do Parlamento lideraram a revolta contra o poder monárquico, que se transformou na Guerra Civil Inglesa, em 1642, e culminou na decapitação de Carlos I em 1649. De 1653 a 1658, a Inglaterra foi governada pelo líder puritano Oliver Cromwell, que foi declarado Lorde Protetor. Sob o Protetorado, ou "Commonwealth", enquanto anglicanos e católicos romanos foram perseguidos religiosamente, tolerância foi estendida aos judeus e a todos os cultos protestantes não-anglicanos, e a legislação puritana tentou reformar a Inglaterra moral e eclesiasticamente (MELNYK, 2008, p. 4-5).

Esta "revolução de santos" não pôde ser estabilizada, de modo que o filho do decapitado Carlos I se tornou rei da Inglaterra em 1660. Embora Carlos II tenha tentado restabelecer a superioridade 
da Igreja, ${ }^{11}$ ele também tinha interesse em acalmar os ânimos religiosos do país - pelo menos, no começo do seu reinado:

Depois da restauração, Carlos II publicou um novo Livro de Oração Comum da Igreja Anglicana (1662) e o Parlamento aprovou um novo "Ato de Uniformidade". Este ato estendeu alguma tolerância aos protestantes não-anglicanos, mas muitos puritanos, bem como batistas, presbiterianos, congregacionalistas e outros não poderiam, em sã consciência, se submeter à nova lei. Eles ficaram conhecidos como "dissidentes" ou "não-conformistas", e foram vistos como potencialmente perigosos para a nova, frágil paz (MELNYK, 2008, p. 5).

Consoante indica o trecho, Carlos II não logrou estabelecer uma paz sustentável, como ficou patente quando ele tentou estabelecer relações mais próximas com a França (católica) e se converteu ao catolicismo pouco antes da sua morte, em 1685. Quando seu irmão, James II, um católico, lhe sucedeu, pela primeira vez desde o reinado de "Maria, a Sanguinária", um católico sentou-se novamente no trono inglês, de modo que a recatolicização da Inglaterra virou uma possibilidade real. Isto, no entanto, era claramente contra a vontade da maioria das elites majoritariamente protestantes e, sobretudo, anglicanas. A percepção de uma ameaça católica e francesa já no reinado de Carlos II, e, mais ainda, no governo de James II, marcou, pelo menos conforme alguns historiadores, as verdadeiras origens do nacionalismo inglês, um nacionalismo similar a uma reação religiosa contra o universalismo católico personificado na figura de Luís XIV.

O ódio inglês a Luís XIV se originava na percepção de seu universalismo. As declarações inglesas de guerra eram baseadas em temores (que cresciam gradualmente desde a entrada da França no segundo conflito anglo-holandês, em 1666) de que Luís tencionasse acabar com a independência de todas as outras nações e se tornar um monarca universal. A despeito de tentativas de limitar a extensão e a ferocidade do sentimento antifrancês, a Inglaterra foi saturada de francofobia pelo reinado de James, e a população estava convencida de que Luís era uma ameaça à integridade nacional não apenas deles mesmos [os ingleses], mas de toda a Europa (PINCUS, 1998, p. 81).

11 O Ato Corporativo de 1661 e o Ato de Prova de 1673 obrigaram todas as corporações e todos os ocupantes de cargos civis e militares a aceitar o sacramento de acordo com os ritos da Igreja Anglicana. Portanto, todas as cidades que não se dispusessem a obedecer não seriam incorporadas e os não-anglicanos seriam expulsos de cargos públicos. 
Logo as críticas ao nacionalismo popular se concentravam diretamente na (possível) aliança entre Luís XIV e Carlos II, e mais tarde entre Luís XVI e James II (PINCUS, 1998). Deste modo, como argumenta Steven Pincus, a "Revolução Gloriosa" de 1688 foi, de fato, a primeira revolução nacionalista, uma revolução bem antifrancesa, com fortes elementos anticatólicos, embora Pincus use de cautela para não superenfatizar os aspectos religiosos deste "evento". ${ }^{12}$

De qualquer forma, as elites anglicanas e protestantes que se revoltaram contra James II pediram a William III de Orange que viesse à Inglaterra, para se livrar dos Stuarts e purificar a Inglaterra do catolicismo e da influência francesa, ou não-inglesa. A "Revolução Gloriosa" e o êxito de William III tiveram algumas consequências, as quais, para o nosso contexto, são ainda mais importantes do que aquelas mencionadas anteriormente e relacionadas ao equilíbrio de poder entre o Parlamento e a Coroa: já em 1689, a convenção constitucional em Londres tinha formulado uma resolução consensual que afirmava que o bem-estar de um Reino Protestante não é compatível com um príncipe papista (CLAYDON; McBRIDE, 1998, p. 3). Esta resolução tornou-se a base para o revolucionário "Ato de Estabelecimento" (1701), assegurando sucessão protestante ao trono. Embora este ato tenha tentado resolver todas as disputas das décadas anteriores e banir definitivamente a ameaça da recatolicização da Inglaterra, ele foi, de fato, o ponto de partida para marcantes decisões, processos e conflitos político-religiosos que viriam ainda nos próximos 130 anos:

[...] o desejo de preservar a nação protestante ocasionaria uma crise na sucessão nos anos 1678-83, legitimaria a deposição do

12 Steven Pincus afirma basicamente que a rebelião contra James não foi causada por sua falsa religião, mas por seu estilo de vida não-inglês. A minimização de fatores religiosos durante a Revolução é justificada, de acordo com Pincus, pelo fato de que, nas guerras do período da Revolução Gloriosa, os "ingleses apoiaram o imperador austríaco, o rei da Espanha e o próprio Papa porque eles estavam envolvidos em luta desesperada para proteger as integridades nacionais contra o aspirante a monarca universal, Luís XIV" (PINCUS, 1998, p. 104). A interpretação de Pincus vai quase paralelamente com a de Liah Greenfeld, já que também ela afirma que os puritanos foram, na verdade, entusiasmados nacionalistas. De acordo com ela, a revolução dos santos não foi tanto religiosa, mas uma revolução nacionalista. Ainda como defende, o foco das ações políticas de Cromwell sempre foi a nação - não muito diferente de John Milton, cujos pensamentos também foram muito definidos por um nacionalismo bastante secular (GREENFELD, 1992). 
rei em 1688, justificaria a união de Inglaterra e Escócia em 1707, importaria uma dinastia em 1714, alimentaria uma crise contínua sobre a emancipação católica entre os anos 1750 e 1829 , e encorajaria a revolução eleitoral de 1832, quando políticos antipapistas buscaram uma legislatura mais "popular", que pudesse defender sua fé (CLAYDON; MCBRIDE, 1998, p. 3).

Enquanto isso, o "Ato de Tolerância" (1689) pelo menos tentou encontrar algum compromisso dentro do protestantismo, tendo permitido que dissidentes protestantes se organizassem em um clima político mais liberal, desde que se mantivessem dentro de uma estrutura política e religiosa mais ampla. Entretanto, também estava claro que dissidentes não tinham os mesmos direitos civis que os anglicanos, porquanto ainda eram proibidos de assumir posições no Parlamento, no exército e nas universidades. A prática política nas décadas e séculos seguintes, no entanto, foi mais indulgente do que as letras da lei. Deste modo, os dissidentes cresceram em número durante o século XVIII (eram 300 ou 400 mil no começo deste século). Não obstante sua parcela da população inglesa nunca ter excedido 7\%, sua influência política e social foi marcante. ${ }^{13}$ Resumindo as consequências do "Ato de Tolerância", há de se dizer que pelo menos a posição monopolizadora da Igreja Anglicana foi abalada, embora a Igreja da Inglaterra ainda fosse vista como a única instituição religiosa legítima.

O Parlamento não estava comprometido com nenhuma visão de que a tolerância era desejável e o pluralismo religioso, inescapável. Tornava-se aparente, no entanto, que a Igreja da Inglaterra provavelmente não voltaria a ser a igreja de toda a nação inglesa, ainda que fosse isso que a hierarquia desejava (ROBBINS, 1998, p. 111-112).

Tolerância, contudo, não significava tolerância em relação aos católicos, pois não apenas a lei, mas também a prática jurídica era mais estrita no tocante a esta forma de dissidência religiosa:

A dissidência católica permaneceu mais deficiente do que a dissidência protestante. Proprietários católicos tinham que pagar taxas territoriais extras. Não havia forma legal de casamento católico. A presença em cultos protestantes era obrigatória a qualquer católico que servisse nas Forças Armadas. Católicos

13 Isto se deu, em parte, pelo fato de os dissidentes estarem concentrados em importantes portos e cidades industriais como Londres, Bristol, Exeter, Birmingham, Sheffield, Leeds e Manchester (ROBBINS, 1998, p. 115; MAURER, 2005, p. 235). 
só podiam assumir funções ante a Coroa no raro caso de estarem dispostos a negar a autoridade espiritual e temporal do Papa e a doutrina da transubstanciação (ROBINS, 1998, p. 116).

Apesar de todas estas medidas discriminatórias, uma comunidade de quase 70 mil crentes no começo do século XVIII sobreviveu na Inglaterra (ROBINS, 1998, p. 116). ${ }^{14}$

Como indicado, a legislação do período pós-1688, e especialmente o Ato de Estabelecimento teve grandes consequências para a identidade inglesa e britânica, sobretudo por causa da união entre Inglaterra e Escócia surgida em 1707 e motivada também por razões religiosas. A união com a Escócia foi certamente diferente daquela com o País de Gales, ocorrida cerca de 180 anos antes. Depois do "Ato de União", em 1536, a área céltica de Gales foi integrada de maneira comparativamente bem-sucedida por meio da introdução do sistema legal inglês e da instituição do inglês como língua oficial, medidas que não causaram grande resistência local. A Escócia, entretanto, foi outro caso.

Durante a maior parte do século XVI, a Inglaterra esteve em guerra com a Escócia. Estas guerras tinham suas bases em questões dinásticas, mas no plano de fundo estava também o fato de que esta última havia desenvolvido uma estrutura religiosa completamente diferente, porquanto a Igreja da Escócia (Kirk of Scotland) era presbiteriana e, desse modo, aderiu a doutrinas muito mais radicais do que a Igreja da Inglaterra. Não obstante, desde o início do século XVII, os tronos inglês e escocês ficaram ligados por união pessoal quando Jacob VI da Escócia (filho de Mary Stuart, "Mary, Rainha dos Escoceses") tornou-se Jacob I da Inglaterra. Desde aquele momento, ambas as coroas foram unidas, embora a Inglaterra e a Escócia permanecessem como reinos separados (com Parlamentos distintos) sob um único monarca.

Contudo, no começo do século XVIII, isto mudou e as causas desta mudança foram, novamente, problemas religiosos ou, sendo mais específico, a sucessão protestante ao trono inglês: a rainha Anne (1702-1714), que sucedera William III no trono inglês, não tinha filhos. Com isto, do ponto de vista dos protestantes ingleses, um antigo perigo parecia iminente em um futuro bem próximo, um

14 Ver também Gilbert (1976, p. 14). 
perigo vindo da Escócia, que - repetindo mais uma vez - mantinha uma união dinástica com a Inglaterra: a recatolicização por meio de um monarca católico no trono da Escócia!

Os políticos de Londres temiam que, a menos que fosse consolidada uma união política formal com a Escócia, distinta da união dinástica existente, o país poderia optar pela morte da pobre infecunda rainha Anne (1702-04) por James Edward Stuart, seu meio-irmão católico romano no exílio (COLLEY, 1992a, p. 12).

Deste modo, uma união política (não apenas dinástica) entre a Escócia e a Inglaterra foi estabelecida para assegurar a Inglaterra (e a Escócia) como uma sucessão protestante ao trono. O propósito da união de 1707 era garantir que a Escócia se comportasse tal como a Inglaterra (e Gales), ou seja, concordasse em "importar uma nova dinastia protestante de Hanover" (COLLEY, 1992a, p. 12). Novamente Colley,

como uma pretensa nação, mais do que um nome, a GrãBretanha foi inventada em 1707, quando o Parlamento de Westminster aprovou o Ato de União, ligando a Escócia à Inglaterra e ao País de Gales. De agora em diante, este documento proclamava, haverá um reino unido sob o nome de GrãBretanha, com um governante protestante, uma legislatura e um sistema de livre comércio [...] (COLLEY, 1992a, p. 11-12).

Esta união política, de fato, era certamente atípica, à medida que a unificação política não foi seguida por uma unificação religiosa (RÉMOND, 2000, p. 49); foi aceita pela Igreja da Inglaterra que na mesma comunidade política (agora, "O Grande Reino da Grã-Bretanha") outra organização religiosa (a Igreja da Escócia) fosse incluída a organização religiosa já existente:

O reino britânico unificado foi incomum em vários aspectos, mas nenhum era mais surpreendente do que sua combinação de uma única legislatura soberana com uma instituição eclesiástica dupla. A preservação de duas igrejas separadas e mutuamente opostas, cada uma com sua própria reivindicação de antiguidade e autonomia territorial, teve profundas implicações no desenvolvimento da consciência nacional. Em um nível prático, havia a questão de se o futuro da Escócia podia ser confiado ao parlamento de Westminster, com sua maioria anglicana embutida nos Comuns e seu componente episcopal nos Lordes. Em um nível ideológico, havia doutrinas rivais relacionadas ao papel do magistrado civil no reino de Cristo (CLAYDON; MCBRIDE, 1998, p. 19). 
Como destacado por Linda Colley, na época do "Ato de União" (1707), a fusão entre Inglaterra e Escócia e, portanto, a criação do "Reino Unido da Grã-Bretanha" dificilmente foi apoiada pela maioria da população inglesa! Ao contrário, muitos ingleses aceitaram a União de maneira relutante, sabendo que a (velha) identidade inglesa teria de mudar. Enquanto a união com Gales no século XVI foi aceita até rapidamente, não foi tão rapidamente esquecido que - repita-se - houve diversas guerras com a Escócia no século XVI, que os "belicosos" escoceses e especialmente os montanheses eram um elemento de certo modo estrangeiro na nova comunidade política (COLLEY, 1992a, p. 13). Assim, como Colley defende, uma identidade nova e consequentemente britânica tinha de surgir no século XVIII, uma identidade capaz de abarcar as antigas e mais locais identidades gaulesa, inglesa e escocesa.

\section{ANTICATOLICISMO, FRANCOFOBIA E PAPEL DO IMPÉRIO: CONTROVÉRSIAS ACERCA DA IDENTIDADE INGLESA OU BRITÂNICA}

Como apontado na introdução, o debate sobre nacionalismo inglês e/ou britânico começou nos anos 1970. No entanto, os primeiros trabalhos importantes sobre o tema só foram publicados a partir dos anos 1980, a maioria deles, fortemente influenciada por interpretações "modernistas" de nacionalismo tais como aquelas de Benedict Anderson (1983), Ernest Gellner (1983) ou Eric J. Hobsbawm (1990). Apesar de algumas diferenças consideráveis de interpretação, todas as abordagens "modernistas" defendem que o nacionalismo foi e é um fenômeno moderno, surgido com a emergência do capitalismo impresso, o começo da industrialização ou a criação do sistema de Estado moderno. Em todo caso, prossegue o argumento dos "modernistas", o fenômeno do nacionalismo somente poderia emergir na modernidade e, portanto, não poderia ser detectado antes do século XVII ou XVIII.

Esta era precisamente a hipótese de A emergência do nacionalismo inglês. Uma história cultural 1740-1830 [The rise of english nationalism. A cultural history 1740-1830] do historiador estadunidense Gerald Newman. Na argumentação do autor, o nacionalismo inglês surgiu na segunda metade do século XVIII, basicamente como uma reação das classes populares inglesas contra os hábitos 
cosmopolitas e francófilos da classe alta inglesa. Especialmente durante o reinado de George II (1727-1760), estas classes populares se sentiram cada vez mais humilhadas, pois a cultura francesa introduzida na Inglaterra era claramente interpretada como uma ameaça aos velhos costumes ingleses. Este sentimento de humilhação foi, então, forçosamente articulado por artistas e intelectuais que se tornaram os mais expressivos grupos portadores deste nacionalismo inglês emergente. Deste modo, não foi por acidente que o nacionalismo inglês nasceu exatamente no momento em que a assim-chamada "Revolução Literária" ocorreu (NEWMAN, 1989, p. 112).

Nos anos 50 [do século XVIII], esta ainda era essencialmente uma campanha por maior influência sobre a moralidade e a cultura inglesa, [conduzida] por um pequeno, mas irritado e crescente número de patriotas culturais antigauleses, como Hogarth e Fielding, Smollet e Foote, uma batalha de uma sensível minoria de artistas-intelectuais contra "o Mundo" e todos os que, impensadamente, a apoiaram, incluindo outros intelectuais e artistas burgueses (NEWMAN, 1987, p. 74).

Consoante Newman afirma, o papel da França como rival militar do século XVIII foi obviamente mais importante na formação da identidade inglesa como uma linguagem ou um território comum. O nacionalismo inglês, portanto, nasceu do ressentimento contra a "dominação cultural francesa" (NEWMAN, 1987, p. 120).

Como deve ter ficado claro por este breve resumo da posição de Newman, ele se colocou conscientemente dentro do campo "modernista" na pesquisa do nacionalismo, sobretudo por sua ênfase na relação entre a emergência dos sentimentos nacionalistas ingleses e a "Revolução Literária" da segunda metade do século XVIII. O nacionalismo inglês, citando-o novamente, foi deliberadamente criado e apoiado por instituições (literárias e artísticas) surgidas naquele período:

A fundação da Sociedade dos Antiquários (1751), a preparação por Johnson de um dicionário de língua inglesa (1755), a inauguração do Museu britânico (1759), a preparação da Biografia britânica (1747-66), a produção da primeira edição da Enciclopédia Britânica (1768-71), o estabelecimento de inúmeras sociedades para o "encorajamento das artes", a escrita, pela primeira vez, das histórias da pintura (1762-80), da música (1776-89) e da poesia (1744-81) inglesas; a fundação da Real Academia (1768) e, 
finalmente, o estabelecimento de uma escola inglesa de pintura - estas foram apenas algumas das manifestações do grande desejo por atividade nesta área, uma enorme expansão no autoestudo, "conscientização" e autopromoção nacional (NEWMAN, 1987, p. 112).

Esta passagem também deixa claro, no entanto, que Newman não fazia nenhuma diferença entre identidades "inglesa" e "britânica". Para o autor, tudo parecia ser a mesma coisa. Desse modo, não pôde perceber que é possível haver um problema empírico e teórico em sua história objetiva do surgimento do nacionalismo inglês. Este foi exatamente o ponto de partida do influente livro de Linda Colley (1992), Britânicos. Forjando a nação [Britons. Forging the Nation 1707-1837].

Colley, já citada neste artigo, tentou pela primeira vez enfrentar a tarefa de explicar a emergência de uma identidade "britânica" distinta de uma identidade inglesa. Como indica o título do seu livro, ela também é uma "modernista", por focar-se nos séculos XVIII e XIX como o período decisivo para o surgimento do nacionalismo britânico. Acima de tudo, Colley destaca o papel da França e do catolicismo na formação de uma identidade genuinamente britânica nas Ilhas: foi o "outro" católico e francês que - de acordo com ela - impulsionou a ideia de uma identidade protestante comum.

A Grã-Bretanha, à época, não era um Estado confessional no sentido estrito. Do contrário, suas leis lhe declaravam uma entidade política pluralista e, ainda, agressivamente protestante. Contudo, não foi a lei que, primordialmente, fez do protestantismo e do anticatolicismo emoções tão poderosas e profundas. A intolerância oficial, como a intolerância da massa, tinha raízes em algo muito mais intangível, principalmente no temor, e na maneira como os bretões escolheram lembrar e interpretar seu próprio passado (COLLEY, 1992a, p. 19).

Porém, como ela percebe ao mesmo tempo, um foco exclusivo no anticatolicismo e na francofobia não pode explicar a emergência da "britanicidade", já que o fortalecimento das identidades nacionais escocesa, gaulesa ou inglesa também seria um resultado possível. Como aconteceu o surgimento de um conceito identitário amplo, uma identidade britânica? A resposta de Colley se concentra especialmente em 1707, nas consequências do "Ato de União" 
e nas peculiaridades sociais e políticas do período, quando George I, o primeiro rei hanoveriano, é seguido da rainha Anne, em 1714. Colley defende, a Inglaterra do século XVIII experimentou grande prosperidade econômica, sobretudo em virtude de todas as barreiras internas de costumes terem sido abolidas pelo fato da União. Surgiu um mercado comum que, em todas as suas várias dimensões, criou um espaço de experiência maior do que a Inglaterra, Escócia ou Gales:

Em termos de produtividade agrícola, a variedade e o volume de seu comércio, a mobilidade geográfica de seu povo, a vitalidade de suas cidades, a onipresença da imprensa, a experiência econômica da Grã-Bretanha neste período foi notavelmente diferente daquela vivida pela maioria do continente europeu (COLLEY, 1992a, p. 43).

Além disto, os sucessos da Grã-Bretanha em termos de política externa, a criação do Império, acentuaram a legitimidade do Regime e do Parlamento, em Westminster, de modo que a União - o Reino Unido da Grã-Bretanha - parecia florescer. Esta legitimidade estava intimamente ligada a interesses materiais dependentes da existência e estabilidade do Império, pelo menos em dois aspectos:

Primeiro, as classes comerciais das Ilhas Britânicas eram profundamente dependentes de lei, ordem e paz interna, logo, cada vez mais, toda ameaça de uma invasão francesa (católica) era uma ameaça direta a seus interesses materiais, o que também significava que a famosa invasão jacobina de 1745-46 recebeu pouco apoio, mesmo na Escócia. Bretões, e isto também significa escoceses, tinham muito a perder economicamente, portanto, calorosas boas-vindas aos rebeldes jacobinos estavam fora de questão (COLLEY, 1992a, p. 85). Porém, as classes comerciais das Ilhas também olhavam para o exterior, não apenas para o continente europeu, mas crescentemente para as áreas não europeias do Império.

[...] mercados continentais para bens britânicos estavam crescendo devagar depois de 1700, em grande parte porque os Estados europeus eram tão agressivamente protecionistas como a própria Grã-Bretanha. Em contraste, o dinamismo comercial do setor imperial - colônias britânicas na América do Norte e nas Índias Ocidentais, e seus postos de comércio na Índia - 
parecia quase não ter limites. Importações vindas da América do Norte quase quadruplicaram em valor na primeira metade do século, importações das Índias Ocidentais mais do que dobraram no mesmo período, enquanto a quantidade de chá trazida para o país pela Companhia das Índias Orientais (diferentemente do que era trazido por contrabandistas, que transportaram muito mais) aumentou em mais de quarenta vezes, indo de pouco mais de 30 toneladas em 1701 para mais de 1.360 toneladas cinquenta anos depois. As exportações para as colônias também aumentaram dramaticamente. Em 1713, mercadores britânicos enviaram algo em torno de £32.400 em exportações para as Carolinas. Em 1739, as exportações para estas mesmas colônias alcançaram sete vezes mais que isso. Ao todo, 95\% do aumento nas exportações de commodities na Grã-Bretanha que ocorreram nas seis décadas posteriores ao Ato de União foram vendidos para mercados cativos e coloniais fora da Europa (COLLEY, 1992a, p. 68-69).

Não é de admirar, portanto, que não a Inglaterra, Gales ou a Escócia, mas o Império Britânico se tornasse o ponto de referência do pensamento político e dos sentimentos nacionais.

Segundo, Colley forçosamente argumenta que os burocratas e soldados gauleses e escoceses também exerceram papel fundamental na administração do Império, de modo que também seus interesses materiais estavam bastante focados na Grã-Bretanha e seu Império. O Império era britânico, e tornou-se ainda mais britânico depois da independência dos Estados Unidos:

As múltiplas guerras e a construção do império naquele período não apenas levaram as classes proprietárias de terras a atuar em conjunto, por causa dos seus próprios interesses, mas também os colocou em um contato sem precedentes com homens e mulheres que eram, inquestionavelmente, alienígenas. Lutar contra americanos nas treze colônias, ou franceses na Europa e Ásia, ou subjugar os desafortunados habitantes da Índia, África, Austrália e das Îndias Ocidentais fez com que fosse muito mais fácil para ingleses, gauleses ou anglo-irlandeses perceber o que tinham em comum (COLLEY 1992a, p.164).

De acordo com Colley, a formação de uma identidade nacional britânica também podia ser vista pelo comportamento dos monarcas daquele período. George I (1714-1727), por exemplo, frequentemente se referia ao seu país de origem (Hanover) e dificilmente poderia ser considerado um inglês ou bretão, em virtude dos seus costumes e linguagem (visitou Hanover mais de cinco vezes durante seu reinado, morreu e foi enterrado lá) (COLLEY, 1992a, p. 201). Isto começou a 
mudar com George II (1727-1760) e George III (1760-1820). George II, em especial, buscou passar a ideia de um "Rei Soldado Protestante" e, assim, tentou parecer um defensor do protestantismo na Europa. Ao agir desse modo, George II impulsionou ainda mais uma identidade britânica comum, uma que se concentrava, sobretudo, no protestantismo (SMITH, 2004).

Contudo, ainda como Colley afirma, por uma série de razões, a ideia de "britanicidade" teve de mudar rapidamente com a chegada do século XIX: sobremodo os elementos anticatólicos e francófobos tinham de desaparecer, já que o cenário político da Europa também havia mudado. Depois da fracassada revolta jacobina de 1745-46, ficou cada vez mais evidente que o catolicismo já não era uma ameaça séria para a nação britânica protestante. A discriminação de católicos começou a enfraquecer, embora dentro das classes populares um forte elemento anticatólico tenha sobrevivido pelo menos até os anos 1830. No entanto, era cada vez mais difícil defender este comportamento, especialmente depois da incorporação da Irlanda em 1801.

A criação do "Reino Unido da Grã-Bretanha e Irlanda" transformou um grande número de católicos em cidadãos da União, de modo que os parâmetros da identidade britânica tinham de ser alterados quase que por necessidade. Como se verá, a questão da emancipação católica estava nos planos da política britânica desde a década de 1770 até a de 1830, quando, em 1829, os direitos civis se tornaram uma realidade para os católicos. ${ }^{15}$ Isto significava quase obrigatoriamente, todavia, que o elemento protestante dentro do nacionalismo britânico deveria ser enfraquecido.

Esta também foi a consequência em relação aos elementos francófobos do nacionalismo britânico. Sobretudo depois da Revolução Francesa e da interpretação laica do Estado francês, não era mais possível associar sentimentos antifranceses e anticatólicos como se fazia no início do século XVIII. Para reforçar, a tentativa de Napoleão Bonaparte de subjugar a Europa novamente

15 Direitos civis, no entanto, não significavam direitos iguais aos dos anglicanos, por exemplo. Mesmo depois de 1829, os católicos eram excluídos do trono; e algumas posições no sistema legal e nas tradicionais universidades britânicas também não eram abertas a eles. 
aumentou os sentimentos antifranceses do nacionalismo britânico. Tal situação, no entanto, começou a mudar quando Napoleão foi derrotado em Waterloo. Desde então, ficou cada vez mais evidente que a França já não era páreo para o Império Britânico; a rivalidade entre a França - ou o "outro" francês - estava mais ou menos acabada.

Com isso, o nacionalismo britânico - afirma Colley - teve claramente de se reconstruir por causa dos processos e eventos mencionados anteriormente:

Entre o estabelecimento da paz, em 1815, e a ascensão da rainha Vitória, em 1837, esta certeza profunda, mas generalizada [em relação aos contornos da identidade britânica] foi posta em foco por três problemas específicos, todos infestados de questões sobre a britanicidade. Primeiro, e mais desafiador, havia os problemas postos pela incorporação da Irlanda ao Reino Unido através do Ato de União de 1800. Mais do que no caso do Ato de União com a Escócia, a causa imediata deste novo arranjo político tinha sido o medo de uma intervenção militar francesa. A Irlanda foi anexada de modo a evitar que Napoleão a usasse como ponto de partida para uma invasão da área britânica continental. No entanto, como astutos contemporâneos reconheceram, não havia nenhuma possibilidade de a Irlanda se reconciliar permanentemente com o governo direto de Westminster, a menos que sua população predominantemente católica tivesse seus direitos civis garantidos. Ainda assim, agora que a Irlanda e a Grã-Bretanha estavam unidas pela lei, como se poderia estender cidadania integral aos católicos irlandeses sem que concessões similares também fossem feitas à minoria católica dentro da própria Grã-Bretanha? (COLLEY, 1992a, p. 322).

Os demais dois "problemas" mencionados por Colley, mas não incluídos no referido trecho, eram os seguintes: o problema (menor) relativo à questão da inclusão política de vários estratos na nação britânica. Como era possível que aqueles que haviam lutado pela nação durante as Guerras Napoleônica e Revolucionária não tivessem o direito de votar? Deste modo, a questão da filiação à nação britânica estava na agenda - uma questão que foi gradualmente respondida por meio das várias reformas eleitorais ao longo do século XIX. A terceira, e muito mais importante questão, de acordo com Colley, estava relacionada à questão de se os escravos também podiam ser membros da nação britânica.

$\mathrm{O}$ argumento de que eles não podiam, e nem deveriam [ser membros da nação], tinha triunfado em 1807, de tal modo que o 
Parlamento baniu o envolvimento britânico no comércio de escravos. Porém, as colônias britânicas nas Índias Ocidentais continuavam dependentes de trabalho escravo. A campanha nacional para persuadir o Parlamento a libertar estes escravos, que culminou com o Ato de Emancipação de 1833 - apenas um ano depois que o primeiro Ato de Reforma remodelou o sistema eleitoral, e quatro anos depois da conquista da emancipação católica, em 1829 - é frequentemente silenciada, ou tratada como uma distração exótica por historiadores do período. Mesmo assim, como o momento sugere, o movimento antiescravagista esteve intimamente ligado com estas outras manifestações sobre cidadania e o significado de britanicidade (COLLEY, 1992a, p. 323-324).

Aqui, o argumento de Colley é de que a questão da escravidão se tornou tão proeminente no discurso político britânico no período entre 1770 e 1830, em especial por uma razão: o clamor pela emancipação destes escravos parecia assegurar os bretões da sua identidade como uma nação livre, uma identidade que tinha sido ameaçada pelos revolucionários americanos, que, em 1776, haviam se declarado os verdadeiros defensores da liberdade. Contudo, a economia dos Estados Unidos da América, agora independentes e soberanos, ainda se baseava em trabalho escravo. Tal situação colocava em xeque sua imagem como uma nação livre.

A reação dos bretões foi a seguinte: "Alardear sua preocupação com o bem-estar dos escravos se tornou a maneira padrão pela qual os bretões mais ortodoxos refutavam as pretensões americanas por liberdades superiores a partir da década de 1860" (COLLEY, 1992a, p. 354). Embora a escravidão ainda fosse uma instituição muito lucrativa, a Grã-Bretanha baniu o envolvimento britânico no tráfico de escravos em 1807 e finalmente emancipou todos os escravos do Império Britânico através do "Ato de Emancipação", o qual foi aprovado pelo Parlamento em 1833. Isto foi feito, segundo Colley, com vistas a definir britanicidade em novos termos. Como o elemento protestante não podia mais ser tão enfatizado quanto o era no século XVIII, um novo tipo de identidade tinha de ser encontrado, um que destacasse, de fato, a liberdade britânica. ${ }^{16}$

16 Nota do tradutor: No original, o autor utiliza os termos freedom e liberty. Embora haja uma diferença de fundo (o primeiro significa "ausência de restriçỗes"; o segundo, "a liberação de uma opressão"), apenas uma palavra serve à sua tradução: "liberdade". 
A emancipação dos católicos, a dos escravos e a ampliação do direito de voto (1832), quase ao mesmo tempo, possibilitaram tal mudança dos elementos da identidade britânica.

Ao aprovar a emancipação católica em 1829, os governantes britânicos inevitavelmente comprometeram o valor do protestantismo como um cimento nacional e grito de mobilização. Contudo, o Ato de Reforma de 1832, juntamente com a libertação dos escravos um ano mais tarde, garantiu ampla compensação a eles [os governantes britânicos] e a todos os outros patriotas britânicos convencionais. Estas ações ajudaram a assegurar que, se os bretões já não podiam mais se posicionar tão confidentemente como sendo exclusiva e unicamente protestantes, eles ainda podiam se ver como diferentes e melhores que seus vizinhos europeus e mesmo que seus antigos colonos americanos. A reforma constitucional pacífica e ordeira e a abolição pioneira e bem-sucedida serviriam a muitos como provas conclusivas da qualidade superior da liberdade britânica (COLLEY, 1992a, p. 361).

Como Colley argumenta, a identidade britânica, criada depois de 1707 e remodelada nas três primeiras décadas do século XIX, não foi capaz de dominar ou destruir outras identidades e lealdades. As antigas identidades escocesa, gaulesa e irlandesa continuaram existindo depois que a já mencionada identidade britânica foi sobreposta (COLLEY, 1992a, p. 327). Assim, deve-se ser cuidadoso para não superenfatizar a estabilidade e rigidez da nova identidade britânica. De acordo com Colley, isto é importante, pois apenas o termo e ideia de uma "sobreposição" de identidade britânica permitem se explicar por que (1) bretões não-protestantes sempre tiveram dificuldade de se incorporar e integrar à Grã-Bretanha e por que (2), depois do declínio do protestantismo e do fim das grandes guerras na Europa, tornou-se cada vez mais difícil definir a "britanicidade", de modo que a separação da Grã-Bretanha no último terço do século XX esteve, de fato, na agenda política (COLLEY, 1992b, p. 327).

Com o desaparecimento do "outro" religioso e político (seja pela perda do inimigo católico, seja pela democratização da Europa ocidental depois de 1945), a Grã-Bretanha perdeu sua capacidade de se definir exclusivamente como protestante ou livre e democrática. Processos de secularização em casa e de democratização em outras áreas do mundo tiraram-lhe suas características distintivas, 
e, assim, as antigas identidades escocesa, irlandesa, gaulesa (e inglesa!) ganharam mais importância e começaram a afastar a superimposta identidade britânica.

Os brilhantes e, portanto, extensivamente citados argumentos de Colley acerca da emergência e do declínio da identidade britânica logo se tornaram centrais no debate sobre nacionalismo inglês e britânico. Não é uma surpresa, óbvio, sua posição ter sido contestada. Pelo menos três críticas de pesquisadores como J. C. D. Clark, Claydon e McBride, e Adrian Hastings se direcionaram especificamente ao argumento principal da autora:

1) Clark questionava se havia sido a guerra, de fato, o principal formador da identidade britânica, como defendido por Colley. De acordo com Clark, é razoável admitir que já existisse algum tipo de identidade nacional (muito provavelmente inglesa) antes das guerras com a França. Além disto, ele não está convencido do papel positivo da guerra no tocante à formação de identidades nacionais, porquanto, guerras, muitas vezes, criam tensões e conflitos internos que não existiam anteriormente (CLARK, 2000, p. 260). Assim, pelo menos a parte da narrativa de Colley centrada na guerra deveria ser vista com alguma desconfiança.

2) Clark também não está convencido da ênfase atribuída por Colley ao papel do protestantismo no nacionalismo inglês/britânico. Segundo ele, não existia o "outro" católico, pois as constelações dentro do protestantismo britânico eram, ao menos, complexas. Enquanto anglicanos mantinham elementos católicos em sua liturgia, isto era execrado pela maioria dos dissidentes. Por isto, muitos dissidentes reuniam católicos e anglicanos na mesma categoria, de modo que a diferenciação tão objetiva de Colley entre católicos e protestantes parece uma maneira bem simplista de representar a realidade (CLARK, 2000, p. 261; HAYDON, 1998, p. 50). Portanto, para Clark, o principal foco (contrário) do discurso das Ilhas foi não o protestantismo, mas o "papismo" - um termo no mínimo nebuloso, que se referia a poder, luxúria, monarquia universal, uniformidade, etc., e que podia ser projetado em praticamente todos os países (não 
apenas na França) (CLARK, 2000, p. 262). ${ }^{17}$ Clark também duvida ter existido uma identidade nacional britânica durante os séculos XVIII e XIX; ele parece preferir falar em uma identidade inglesa, cujas origens remontam aos meados do século XII, embora admita que o anglicanismo foi crucial na formação e, acima de tudo, na estabilização da identidade inglesa (CLARK, 2000, p. 274).

3) Claydon e McBride também afirmaram que definir o protestantismo como uma característica decisiva na identidade nacional esbarrava em dificuldades "lógicas", porquanto, evidentemente, a Grã-Bretanha não era a única nação protestante. Assim, fica difícil entender como apenas o povo inglês deveria ser "O povo escolhido" (CLAYDON; McBRIDE, 1998, p. 13). Além do mais, como havia grandes diferenças no interior dos vários protestantismos, não fica realmente claro como alguém deveria pensar no protestantismo como elemento decisivo da identidade britânica, conforme sugerido por Colley.

Dados estes problemas modernos iniciais com a britanicidade protestante, é válido questionar se a fé renovada poderia ser, algum dia, uma base confiável para uma identidade nacional unificadora. O senso comum protestante de que a igreja verdadeira é algo místico, mais do que humano; sua missão universalista de converter toda a humanidade; sua tendência às fissuras; sua fácil adoção da retórica divisionista do antipapismo em disputas internas; e sua suspeita da tentativa de impor acordos em virtude da perseguição papista: tudo isto fez do protestantismo um fundamento improvável de nacionalidade no início do período moderno (CLAYDON; MCBRIDE, 1998, p. 14-15).

Claydon e McBride, portanto, destacam outros elementos da identidade britânica, além do protestantismo, como Colley fez, isto é, uma linguagem comum, a crença na liberdade constitucional, em uma descendência racial, em um relacionamento especial com a Europa continental, etc. (CLAYDON; McBRIDE, 1998, p. 9). Isto não significa que o protestantismo não tenha exercido nenhum papel. Pelo contrário! Como afirmam os autores, o protestantismo não foi

17 Alguns historiados duvidam até mesmo que a ideia de "papismo" fosse tão unitária e significativa como sugerido por Clark: Embora o antipapismo "possa ter sido um elemento-chave na discussão pública na Inglaterra do século XVIII, [...] seu uso constante não resultou em uma campanha de anticatolicismo homogênea" (BLACK, 1998, p. 62). 
um elemento fixo da identidade britânica; ele foi mais a aspiração para criar uma nação protestante "sagrada", que uniu vários grupos protestantes dentro das Ilhas (CLAYDON; MCBRIDE, 1998, p. 19).

[...] O modelo aspiracional leva a sério as desvantagens das nações britânicas como comunidades protestantes. Isto sugere que os próprios contemporâneos estavam profundamente cientes destas desvantagens e chegaram até a incorporar esta consciência em sua autopercepção, retratando-os como um povo com a missão de criar uma sociedade completamente protestante (CLAYDON; MCBRIDE, 1998, p. 29. Destaque no original).

Alguns destes argumentos contra o posicionamento de Colley certamente criticam sua abordagem "modernista" no estudo do nacionalismo em geral. É evidente que, por exemplo, subestimar o elemento protestante dentro do nacionalismo britânico significa, ao mesmo tempo, buscar outras raízes (geralmente mais antigas) de sentimentos nacionalistas, como uma linguagem comum, etc. Tal busca tem certamente de voltar muito mais no tempo do que já foi feito, por exemplo, por Liah Greenfeld, o qual, conforme exposto, se concentrou bastante no período entre 1540 e 1640, e, deste modo, declarou ter detectado as raízes do nacionalismo bem antes de Colley.

Como visto, J. C. D. Clark tenciona voltar pelo menos até o século XII, o que também é feito por Adrian Hastings (1997), cujo livro A construção da nacionalidade, etnicidade, religião e nacionalismo [The construction of nationhood, ethnicity, religion and nationalism] se tornou uma das mais ambiciosas críticas da abordagem "modernista" de Colley no estudo do nacionalismo britânico. Hastings concorda com Colley, afirmando que o nacionalismo britânico surgiu no século XVIII (HASTINGS, 1997, p. 5). Porém, bem ao contrário das premissas de Colley, ele também argumenta que (em concordância com J. C. D. Clark), antes daquele momento, havia um nacionalismo inglês forte e crescente, considerado um dos fatores decisivos para a modernização da Inglaterra, e que teve suas origens na Idade Média, algo fortemente ignorado por Colley. ${ }^{18}$

Como Hastings argumenta, buscar as raízes medievais do nacionalismo não implica buscar por laços primordiais, como, em geral, é erradamente assumido. De acordo com Hastings, tal busca

18 Para uma crítica profunda do argumento de Hastings, ver Kumar (2003, p. 43). 
é improdutiva porque propõe as questões erradas. As abordagens mais promissoras não tentam descobrir referidos laços de modo a explicar o nacionalismo; elas simplesmente tentam responder à questão de por que alguns grupos étnicos se tornaram nações e outros não.

Defenderei que etnias se tornam nações ou elementos integrais naturalmente no momento em que seu vocabulário específico se transforma de um uso oral para o uso escrito de tal maneira que passa a ser usado regularmente na produção de uma literatura e, particularmente, para a tradução da Bíblia. Uma vez que o vocabulário de uma etnia se torna uma linguagem com extensa literatura, o rio que cruza a estrada rumo à nacionalidade parece ter sido cruzado (HASTINGS, 1997, p. 12).

Assim, para Hastings, uma linguagem escrita parece ser crucial para a estabilização de uma identidade nacional; e, de acordo com ele, a Inglaterra foi um caso de sorte neste aspecto, porquanto sua posição nas Ilhas garantiu, por um lado, algum isolamento do continente europeu, mas permitiu, por outro lado, pelo menos alguma competição com a linguagem e a cultura escocesas, por exemplo, de modo que a necessidade de institucionalização da língua inglesa mediante fundação de universidades, etc., tornou-se evidente (HASTINGS, 1997, p. 42). Uma linguagem vernacular institucionalizada garantiu a emergência do nacionalismo inglês e sua estabilização logo cedo, iniciando, desse modo, processos de modernização nas Ilhas Britânicas:

Seria certamente surpreendente que a Inglaterra não estivesse presente no início de um processo que foi tão central para o desenvolvimento político do mundo moderno. Surpreendente porque a Inglaterra claramente exerceu a liderança em relação a muitos aspectos deste desenvolvimento, como o estabelecimento de um Estado fortemente centralizado, o crescimento do governo parlamentarista, eletivo e representativo, o declínio inicial do feudalismo, a limitação do poder real, a emergência de uma capital poderosa, a formação de partidos políticos, o fim da escravidão, a emergência da sociedade industrial e de uma imprensa efetiva (HASTINGS, 1997, p. 6).

Hastings, portanto, tem uma imagem bem peculiar da relação entre a identidade inglesa e a britânica. Ele defende a existência simultânea do nacionalismo inglês e britânico e destaca, ao mesmo tempo, a predominância da identidade inglesa sobre a britânica (HASTINGS, 1997, p. 63): enquanto a identidade inglesa tinha sido, 
de fato "firmemente protestante" desde o século XVII, um nacionalismo britânico bem secular surgiu após a década de 1750, quando, finda a Guerra dos Sete Anos (a "Guerra francesa e indígena"), um grande número de quebequenses (católicos) se tornou parte do Império. Embora neste aspecto a diferença em relação à Colley seja pequena, permanece o fato de que Hastings enfatiza muito mais do que ela o papel do nacionalismo inglês para a ascensão da Grã-Bretanha a potência mundial.

As críticas ao trabalho de Colley certamente tiveram alguns pontos marcantes. Em sua defesa, no entanto, há de se dizer que a imagem que ela faz de uma identidade britânica distinta no século XVIII continua válida. Assim, o debate não era tão centrado em uma completa negação dos argumentos de Colley, mas em algumas revisões relativamente menores. Uma destas revisões, para a qual já apontamos, era uma maior ênfase no papel do Império para o nacionalismo britânico. Este ponto com certeza não foi ignorado por Colley, mas sem dúvida poderia ter sido ainda mais destacado. Peter Van der Veer tentou fazer isto em um importante ensaio (1999), intitulado O Estado moral: religião, nação e Império na Grã-Bretanha vitoriana e na Índia britânica [The moral State: religion, nation, and Empire in Victorian Britain and British Índia].

Os argumentos de Van der Veer geralmente seguem a narrativa de Colley bem de perto. Sua contribuição genuína, no entanto, começa quando ele afirma que no século XVIII o evangelismo britânico, especialmente o metodismo (e o wesleyanismo), foi capaz de resolver as diferenças entre anglicanos e dissidentes, que já durava bastante tempo e que desde a segunda metade do século XVII tinha tido graves consequências. Assim, de acordo com Van der Veer, o evangelismo metodista se tornou um tipo de movimento nacionalista que uniu diversos grupos protestantes dentro e fora da Igreja da Inglaterra. ${ }^{19}$ Isto explica, e tem de ser visto como uma defesa e um complemento do argumento de Colley, de que modo o protestantismo, apesar de todas as suas divergências internas, conseguiu atingir algum tipo de unidade para definir o "outro" católico.

19 Para saber sobre o metodismo wesliano, cf. Gilbert (1976, p. 21) e Hempton (1996, p. 27). 
Todavia, conforme Van der Veer argumenta, este grande "guarda-chuva" protestante não funcionou por muito tempo: embora houvesse uma mistura bem próxima de ideias evangélicas e liberais que formou um fundamento relativamente sólido da política cultural britânica do século XIX, rapidamente tornou-se claro que a integração de católicos não podia ser garantida ainda por muito tempo por via dos antigos meios ideológicos; de modo paradoxal, depois da emancipação católica em 1829, as divisões religiosas dentro da Grã-Bretanha (agora entre protestantes e católicos) tinham crescido tanto que um substituto precisava ser encontrado. Este foi o momento em que a ideia de uma "missão imperial" empurrou a religião para o segundo plano e os conceitos de "superioridade racial" (VAN DER VEER, 1999, p. 27) floresceram, de modo que a raça pudesse substituir a religião e, portanto, o protestantismo como elemento definidor do nacionalismo britânico.

A imagem que Van der Veer faz das características raciais do nacionalismo britânico durante a Era Vitoriana é certamente intrigante, já que parece abarcar os inúmeros preconceitos raciais da política colonial e imperial da Grã-Bretanha (e de todas as grandes potências europeias). Contudo, o posicionamento de Van der Veer também foi desafiado. Como Peter Mandler, em especial, afirma, na segunda metade do século XIX, o pensamento político e o discurso intelectual britânico (e isto também se aplica ao conservadorismo britânico) têm se destacado por sua ausência de categorias raciais e metáforas orgânicas. O debate sobre o caráter britânico, prossegue Mandler, dificilmente foi influenciado por questões de "raça" (MANDLER, 2001, p.124), e por boas razões: com a finalidade de preservar a ordem social hierárquica nas Ilhas, para as elites britânicas era tão importante enfatizar questões de classe quanto de raça. Assim, o discurso de uma missão civilizadora universal (sem muitas referências à raça) se tornou dominante: só era possível preservar o status quo com a afirmação de que as raças (isto é, as classes baixas) na Grã-Bretanha eram tão adequadas a uma missão civilizadora quanto as não-europeias. Deste modo, consoante Mandler (2000, p. 232), o pensamento racial (tal como aludiu Van der Veer) nunca foi tão proeminente na Grã-Bretanha quanto nas outras nações europeias. 
No geral, parece razoável não se enfatizar demais a questão de raça ao se descrever as características peculiares do nacionalismo britânico da Era Vitoriana. A este respeito, a meu ver, a posição de Hugh McLeod (iminente historiador da religião na Europa) parece ser ainda a mais razoável. De acordo com McLeod (1996), durante o século XIX, a Inglaterra ainda era um país muito religioso, o que moldou decisivamente suas identidades nacionais. Ao contrário de alegações de uma secularização completa da vida cotidiana já naquele período, McLeod afirma que entre 1850 e 1914 ainda existia algum tipo de consenso protestante na Inglaterra - apesar da emancipação católica e do declínio das atividades religiosas, especialmente no período entre 1886 e 1903 (McLEOD, 1996, p. 171). ${ }^{20}$ Posicionamentos completamente seculares - ateísmo, agnosticismo e anticlericalismo - permaneceram relativamente fracos, sobretudo por conta de ser o liberalismo inglês (e britânico) altamente influenciado pela contribuição de dissidentes religiosos. Assim, faltava na Inglaterra (e na Grã-Bretanha) um liberalismo secular que era tão forte em muitos países europeus. O mesmo se aplica ao socialismo, que teve suas raízes no liberalismo (religioso) e, portanto, nunca desenvolveu uma dinâmica anticlerical que, muitas vezes, podia ser observada na Europa continental (McLEOD, 1996, p. 2).

Como McLeod apoia o argumento de Colley segundo o qual o anticatolicismo começou a enfraquecer durante o século XIX e perdeu completamente sua lógica depois da separação da Irlanda, em 1921, ele afirma que, entre 1815 e 1915, o nacionalismo britânico consistiu de cinco elementos centrais: 1. Cristianismo, em oposição a uma França laica e aos pagãos não-europeus; 2. Protestantismo, em oposição à Irlanda, ao catolicismo e ao papismo; 3. Prosperidade, em oposição às regiões subdesenvolvidas

\footnotetext{
20 McLeod explica que o declínio religioso neste período foi influenciado pela emergência da indústria do lazer, que deu especialmente às mulheres uma chance de deixar a privacidade do lar sem serem forçadas a se envolver em atividades religiosas. Deste modo, a indústria do lazer foi uma recém-criada válvula de escape para mulheres que tradicionalmente tinham sido o grupo mais importante de portadores das atividades religiosas: "Este grande crescimento, por volta de 1870, foi em formas de diversão independentes do pub e podiam ser (embora nem sempre fossem) independentes da igreja. Os maiores desenvolvimentos incluíam a emergência do esporte como uma febre nacional, o crescimento de várias formas de teatro popular, o surgimento de resorts populares de final de semana, e a emergência de uma imprensa de jornais populares diários" (MCLEOD, 1996, p. 197).
} 
da Europa e do mundo; 4. Civilização, em oposição às classes e raças não-civilizadas; e 5. Liberdade, as conquistas da Revolução Gloriosa em oposição aos regimes autocráticos do continente europeu (McLEOD, 1999, p. 46). Já que especialmente os elementos religiosos desta lista foram se tornando cada vez mais obsoletos, é bastante compreensível que no século XX tenha ficado particularmente difícil reviver a ideia de "britanicidade". No primeiro terço do século XX, a referência a um Império (secular) ainda funcionava, mas foram necessários Hitler e o antinazismo para atiçar novamente estes sentimentos britânicos (McLEOD, 1996, p. 63). Assim, como evidenciado, depois de 1945, a identidade nacional britânica foi cada vez mais ameaçada por outra, possivelmente mais antiga, forma de identidade coletiva.

Resumindo todos estes debates sobre nacionalismo inglês/britânico no século XVII e ao longo do século XIX, as interpretações seguintes, um tanto discrepantes, sobre a essência e a lógica do "Reino Unido da Grã-Bretanha e Irlanda do Norte" (como existe atualmente) são possíveis:

Interpretação 1 - alega que a Grã-Bretanha nunca foi uma nação, mas tão-somente um Estado multinacional. ${ }^{21}$ Nas palavras de Keith Robbins:

Se aceitarmos que o estabelecimento do Estado Irlandês Livre [em 1921] representou [...] o triunfo do "nacionalismo irlandês", então, é autoevidente que o Reino Unido do século XIX era, em realidade, um Estado multinacional. A ruptura, quando ela ocorreu, foi o resultado da incapacidade de duas nacionalidades, "britânica" e "irlandesa", de funcionar juntas e eficazmente em um Estado. Nesta leitura, portanto, a União de 1800, longe de ser o estágio final na formação do Reino Unido, como alguns vitorianos julgaram, foi meramente um arranjo temporário que não tinha nem mesmo a possibilidade de uma viabilidade duradoura (ROBBINS, 1995, p. 246).

Assim, a separação posterior da Grã-Bretanha, e o prognóstico conclusivo desta primeira interpretação, parece possível!

Interpretação 2 - alega exatamente o contrário: a Grã-Bretanha foi e é um Estado-nação. A existência de múltiplas identidades nacionais - a posse das identidades gaulesa e britânica, escocesa e

21 Ver, por exemplo, McCrone (1997, p. 585). 
britânica, irlandesa e britânica, ao mesmo tempo - não diz nada a respeito do futuro do Estado britânico. Múltiplas identidades coletivas certamente não devem ser interpretadas como uma ameaça à unidade política das Ilhas Britânicas, já que estas múltiplas identidades têm existido por longo tempo. Não há nenhuma lógica na dissolução do Reino Unido da Grã-Bretanha e Irlanda do Norte como ele existe hoje (ROBINS, 1995, p. 246).

Há bons argumentos para ambas as interpretações e prognósticos políticos. Talvez a reação mais convincente a estas interpretações divergentes venha do sociólogo britânico Krishan Kumar. Seu argumento é simples: nenhuma destas interpretações está completamente certa, pois ambas compreendem de modo errado o caráter específico do nacionalismo britânico que se desenvolveu desde o começo do século XVIII. Como alega Kumar, o nacionalismo britânico era um nacionalismo "missionário" ou "imperial", diferentemente da maioria dos nacionalismos do continente europeu. Este nacionalismo missionário dificultou bastante que os ingleses (e britânicos) pudessem se ver como apenas uma nação entre tantas. Deste modo, o Império sempre foi e tem sido uma parte central não apenas do nacionalismo britânico, mas também do nacionalismo inglês. Ao contrário de Clark, Hastings e também Colley, Kumar afirma que não havia um nacionalismo cultural inglês antes do fim do século XIX. Assim, não é correto alegar (COmo o fez Colley) que o nacionalismo britânico foi de algum modo sobreposto à identidade nacional inglesa. Simplesmente não havia identidade inglesa, porquanto foi este nacionalismo missionário, sem nenhum componente cultural evidente, que definiu "inglesidade" (e "britanicidade" ao mesmo tempo). A identidade inglesa sempre foi e continua sendo particularmente subdesenvolvida: ${ }^{22}$ não havia nenhum equivalente para Herder, Fichte, Grimm, Savigny (KUMAR, 2003, p. 184) meramente porque os ingleses sempre tiveram o passado imperial em suas tentativas de se definir, um passado (missionário) que tornou impossível a definição de inglesidade apartada da sua missão imperial.

22 Como Kumar explica, foi apenas ao final do século XIX que um nacionalismo cultural particularmente fraco começou a se desenvolver na Inglaterra. Um nacionalismo cultural, porém, que não sobreviveu por muito tempo, até que novas tentativas foram feitas por conservadores ingleses no final da década de 1980 (KUMAR, 2000, p. 592). 
Em consequência, o caminho futuro da Grã-Bretanha continua em aberto: embora tenha havido algumas tentativas recentes do Partido Conservador, sob a liderança de Thatcher e Major, lde reviver algum tipo de identidade (cultural) nacional inglesa (depois da perda de quase todos os assentos eleitorais na periferia céltica), ainda resta ver se isto acontecerá e em que direção. Se bem interpreto Kumar, os sucessores de Thatcher e Major enfrentarão algumas dificuldades, pois a questão "o que é inglês" é bastante difícil de responder sem se fazer referência ao Império; um Império, contudo, que já se foi. Consequentemente, continua em aberto quão fortes os nacionalismos escocês, gaulês ou irlandês vão se tornar caso, de fato, os ingleses fracassem em desenvolver sentimentos nacionalistas genuínos. Assim, a futura separação da Grã-Bretanha não deve ser dada como certa.

\section{CONCLUSÃO}

O que não foi coberto pelo esquema histórico-sociológico do desenvolvimento britânico/inglês são os seguintes períodos históricos, os quais parecem abranger alguns grandes problemas de interpretação, pois a literatura a este respeito é relativamente reduzida em termos dos problemas que nos interessam:

a) Não está claro, até agora, como o nacionalismo britânico/inglês se desenvolveu durante a Primeira Guerra Mundial, quando o "Irish Home Rule" foi um dos problemas decisivos: houve uma revitalização de elementos protestantes dentro do nacionalismo britânico/inglês, embora a França, seu mais importante aliado no continente europeu, fosse católica e/ou laica?

b) Praticamente as mesmas questões devem ser colocadas em relação à Segunda Guerra Mundial e à Guerra Fria. Houve uma revitalização dos elementos religiosos do nacionalismo britânico/inglês em face do nazismo? Como a Guerra Fria e a ameaça por outro poder totalitário e bastante secular (a URSS) influenciaram o nacionalismo nas Ilhas Britânicas?

c) Quais os efeitos da criação da Commonwealth britânica, do Estatuto de Westminster (1931) e dos processos de descolonização após a Segunda Guerra Mundial nas identidades nacionais? 
Somente se estas questões de pesquisa forem devidamente respondidas, um esboço plausível do impacto da União Europeia no nacionalismo britânico será possível. O que não fica claro de modo algum para mim, no entanto, é a questão do foco principal do meu próximo artigo: deveria tratar da identidade nacional inglesa (escocesa, gaulesa) ou britânica, caso isto possa de algum modo ser separado? Um debate sobre este importante ponto seria muito bem-vindo.

Tradução: Camila Alves da Costa

\section{REFERÊNCIAS}

ANDERSON, B. Imagined communities. Reflections on the origin and spread of nationalism. London: Verso, 1983.

Die entstehung des absolutistischen staates.

Frankfurt: M., Suhrkamp,1979.

BENDIX, R. Könige oder Volk. Machtausübung und herrschaftsmandat. Frankfurt: M., Suhrkamp, 1980. 2 v.

BLACK, J. Confessional state or elect nation? Religion and identity in eighteenth-century England. In: CLAYDON, T. M.;McBRIDE,

I. (Eds.). Protestantism and national identity. Britain and Ireland, c. 1650-c.1850. Cambridge: Cambridge UP, 1998. p.53-74.

BREWER, J. The sinews of power. War, money and the English state, 1688-1783. London: Wellington;Boston: Unwin Hyman, 1989.

BROWN, C. G. The death of Christian Britain. Understanding secularisation 1800-2000. London; New York:Routledge,2001.

CANNADINE, D. British history as a 'new subject'. In: GRANT, A. S.; STRINGER, K. J. (Eds.). Politics, perspectives and prospects. Uniting the kingdom? The making of British history. London; New York: Routledge, 1995. p. 12-28.

CLARK, J. C. D. Protestantism, nationalism, and national identity, 1660-1832.The Historical Journal, v. 43, n. 1, p. 249-276, 2000. 
CLAYDON, T. M.; McBRIDE, I. The trials of the chosen peoples: recent interpretations of protestantism and national identity in Britain and Ireland. In: (Eds.). Protestantism and national identity. Britain and Ireland, c.1650-c.1850. Cambridge: Cambridge UP, 1998. p. 3-29.

COLLEY, L. Britons.Forging the nation 1707-1837. New Haven; London: Yale UP, 1992a. . Britishness and otherness: an argument. Journal of British Studies, v. 31, n. 1, p. 309-329,1992b. CORRIGAN, Ph.; SAYER, D. The great arch. English state formation as cultural revolution. Oxford: Basil Blackwell,1985.

DYSON, K. H. F. The state tradition in western Europe. A study of an idea and institution. Oxford: Robertson,1980.

EHLERS, J. Mittelalterliche voraussetzungen für nationale identität in der neuzeit. In: GIESEN,B. (Ed.). Nationale und kulturelle identität. Studien zur entwicklung des kollektiven bewußtseins in der neuzeit. Frankfurt: Main, Suhrkamp, 1991. p. 77-99.

GELLNER, E. Nations and nationalism. Oxford: Basil Blackwell,1983.

GERSTENBERGER, H. Die subjektlose gewalt. Theorie und entstehung bürgerlicher herrschaft. Münster: Westfälisches Dampfboot, 1990.

GILBERT, A. D. Religion and society in industrial England. Church, Chapel and Social Change, 1740-1914. London; New York: Longman, 1976.

GRABES, H. England oder die Königin? Öffentlicher meinungsstreit und nationale identität unter Mary tudor. In: GIESEN, B. (Ed.). Nationale und kulturelle identität. Studien zur entwicklung des kollektiven bewußtseins in der neuzeit. Frankfurt: Main, Suhrkamp, 1991.p. 121-168.

GREENFELD, L. Nationalism. Five roads to modernity. Cambridge: Mass.; London: Harvard UP,1992.

HAAN, H.; NIEDHART, G. Geschichte Englands vom 16. bis zum 18.Jahrhundert. München: C.H. Beck,1993. 
HARLING, P. M., MANDLER, P. From 'fiscal-military' state to laissez-faire state, 1760-1850. Journal of British Studies, v. 32, n. 1, p. 44-70, 1993.

HASTINGS, A.The construction of nationhood.Ethnicity, religion and nationalism. Cambridge: Cambridge UP,1997.

HAYDON, C. I love my king and my country, but a roman catholic I hate: anti-catholicism, xenophobia and national identity in eighteenth-century England.In: CLAYDON, T. M.; MCBRIDE,I. (Eds.). Protestantism and national identity. Britain and Ireland, c.1650-c.1850. Cambridge: Cambridge UP, 1998. p.33-52.

HEMPTON, D. Religion and political culture in Britain and Ireland. From the glorious revolution to the decline of empire. Cambridge: Cambridge UP,1996.

HILL, Chr. Über einige geistige konsequenzen der Englischen Revolution. Berlin: Wagenbach, 1990.

HOBSBAWM, E. J. Nations and Nationalism since 1780. Cambridge: Cambridge UP, 1990.

KENNEDY, P. The rise and fall of the great powers. Economic change and military conflict from 1500 to 2000. London: Fontana Press, 1990.

KLUXEN, K. Geschichte und problematik des

parlamentarismus. Frankfurt: M., Suhrkamp,1983.

KRIEGER, K. F. Geschichte Englands von den Anfängen bis zum 15. Jahrhundert. München: C.H. Beck,1990.

KUMAR, K. The making of English identity. Cambridge: Cambridge UP, 2003.

Nation and Empire: English and British national identity in comparative perspective. Theory and Society, v. 29, p. 575-608,2000.

LACHMANN, R. Elite conflict and state formation in 16th- and 17th-Century England and France. American Sociological Review, v. 54, n. 1, p. 141-162,1989.

LANGFORD, P. A polite and commercial people. England 1727-1783. Oxford: Clarendon Press, 1989. 
MADELEY, J. T. S. A framework for the comparative analysis of church-state relations in Europe. West European Politics, v. 26, n. 1, p. 23-50, 2003.

MANDLER, P. The consciousness of modernity? Liberalism and the English National Character, 1870-1940. In: DAUNTON, M. R.; RIEGER, B. (Eds.). Meanings of modernity. Britain from the Late-Victorian Era to World War II. Oxford; New York: Berg, 2001. p.119-144.

.'Race' and 'nation' in mid-Victorian thought. In: COLLINI,S. W.; WHATMORE,R.; YOUNG,B.; BRIAN (Eds.). History, religion, and culture. British Intellectual History 1750-1950. Cambridge: Cambridge UP, 2000. p.224-244.

MARR, A. The day Britain died. London: Profile Books,2000. MAURER, M. Kleine geschichte Englands. Stuttgart: Reclam, 2005.

MCCRONE, D. Unmasking Britannia: the rise and fall of British national identity. Nations and Nationalism, v. 3, n. 1, p. 579$596,1997$.

MCLEOD, H. Protestantism and British national identity.Nation and religion. In: van der VEER, P. L.; LEHAMNN, H. (Eds.).

Perspectives on Europe and Asia. Princeton: Princeton UP, 1999. p.44-70.

Religion and society in England, 1850-1914. Houndsmill:MacMillan Press, 1996.

MELNYK, J. Victorian religion. Faith and life in Britain. Westport: Conn.; London: Praeger,2008.

NAIRN, T. The break-up of Britain. New Edition. London: Verso, 1981 [1977].

NEWMAN, G. The rise of English nationalism. A cultural history 1740-1830. New York: St. Martin's Press,1987.

PINCUS, S. To protect English liberties: the English nationalist revolution of 1688-1689. In: CLAYDON, T. M.; McBRIDE,I. (Eds.).

Protestantism and national identity. Britain and Ireland, c.1650-c.1850.Cambridge: Cambridge UP, 1998. p. 75-104. 
POCOCK, J. G. A. The limits and divisions of British history: in search of the unknown subject. The American Historical Review, v. 87, n. 2, p. 311-336,1982.

British history: a plea for a new subject. Journal of Modern History, v. 47, n. 4, p. 601-621,1975a.

The Machiavellian moment. Princeton: Princeton

UP, 1975b.

REINHARD, W. Staat und heer in England im zeitalter der revolutionen. In:KUNISCH, J. (Ed.). Staatsverfassung und heeresverfassung in der Europäischen geschichte der frühen neuzeit. Berlin: Duncker \& Humblot, 1986.p. 173-212.

RÉMOND, R. Religion und gesellschaft in Europa. Von 1789 bis zur gegenwart. München: C.H. Beck,2000.

ROBBINS, K. Great Britain. Identities, institutions and the idea of Britishness. London/New York: Longman,1998.

An imperial and multinational polity. The 'scene form the centre', 1832-1922. In: GRANT, A. S.; STRINGER, K. J. (Eds.). Uniting the kingdom? The making of British history. London; New York: Routledge, 1995. p.244-254.

History, religion and identity in modern

Britain.London; Rio Grande: The Hambledon Press,1993.

SCHILLING, H. Nationale identität und konfession in der europäischen neuzeit. In: GIESEN, B. (Ed.). Nationale und kulturelle identität. Studien zur Entwicklung des kollektiven Bewußtseins in der Neuzeit. Frankfurt: Main, Suhrkamp, 1991. p. 192-252.

SCHRÖDER, H. C. Die revolutionen Englandsim 17. Jahrhundert. Frankfurt: M., Suhrkamp,1986.

SHEPHERD, Willian R. Historical Atlas. New York: Henry Holt Company, 1923.

SMITH, A. G. R. The emergence of a nation-state. The commonwealth of England, 1529-1660. London: Longman, 1984.

SMITH, H. The idea of a protestant monarchy in Britain 17141760. Past and Present, v. 185, p. 91-118, 2004. 
SPECK, W. A. Stability and strife. England 1714-1760. London: Edward Arnold, 1977.

SPOHN, W. Nationalismus und religion. Ein historischsoziologischer Vergleich West-und Osteuropas. In: MINKENBERG; WILLEMS (Eds.). Politik und religion. [S.l.: s.n.], 2002. p. 323345. (PVS-Sonderheft 33).

STRAYER, J. R. On the medieval origins of the modern state. Princeton: Princeton UP, 1970.

THANE, P. Government and society in England and Wales. In: THOMPSON, F. M. L. (Ed.). The Cambridge social history of Britain 1750-1950. Cambridge: Cambridge UP, 1990. v. 3 Social Agencies and Institutions, p. 1-61.

VAN DER VEER, P. The moral state: religion, nation, and Empire in Victorian Britain and British India. In: VAN DER VEER, P. L.; LEHMANN, H. (Eds.). Nation and religion. Perspectives on Europe and Asia. Princeton: Princeton UP, 1999. p. 15-43.

VON GREYERZ, K. England im jahrhundert der revolutionen 1603-1714. Stuttgart: UTB, 1994

WENDE, P. Das Britische empire. Geschichte eines Weltreichs. München: C.H. Beck, 2008.

WOLFFE, J. God and greater Britain. Religion and national lifein Britain and Ireland 1843-1945. London; New York:

Routledge, 1994. 